\title{
Paths and strategies for sustainable urban renewal at the neighbourhood level: A framework for decision-making
}

DOI:

10.1016/j.scs.2020.102074

\section{Document Version}

Accepted author manuscript

Link to publication record in Manchester Research Explorer

\section{Citation for published version (APA):}

Huang, L., Zheng, W., Hong, J., Liu, Y., \& Liu, G. (2020). Paths and strategies for sustainable urban renewal at the neighbourhood level: A framework for decision-making. Sustainable Cities and Society, 55, [102074].

https://doi.org/10.1016/j.scs.2020.102074

\section{Published in:}

Sustainable Cities and Society

\section{Citing this paper}

Please note that where the full-text provided on Manchester Research Explorer is the Author Accepted Manuscript or Proof version this may differ from the final Published version. If citing, it is advised that you check and use the publisher's definitive version.

\section{General rights}

Copyright and moral rights for the publications made accessible in the Research Explorer are retained by the authors and/or other copyright owners and it is a condition of accessing publications that users recognise and abide by the legal requirements associated with these rights.

\section{Takedown policy}

If you believe that this document breaches copyright please refer to the University of Manchester's Takedown Procedures [http://man.ac.uk/04Y6Bo] or contact uml.scholarlycommunications@manchester.ac.uk providing relevant details, so we can investigate your claim.

\section{OPEN ACCESS}


Paths and strategies for sustainable urban renewal at the neighbourhood level: A framework for decision-making

Lijie HUANG, Wei ZHENG, Jingke HONG*, Yong LIU, Guiwen LIU

\section{Author details:}

Lijie Huang, School of Management Science and Real Estate, Chongqing University, Chongqing 400045, China

Email address: 20140073@cqu.edu.cn

Wei Zheng, Department of Planning and Environmental Management, Manchester Urban Institute, The University of Manchester, Manchester, M13 9PL, UK

Email address: helen.zheng@manchester.ac.uk

Jingke Hong, School of Management Science and Real Estate, Chongqing University, Chongqing 400045, China

Email address: hongjingke@,cqu.edu.cn

Yong Liu, School of Management Science and Real Estate, Chongqing University, Chongqing 400045, China

Email address: liuyong80@cqu.edu.cn

Guiwen Liu, School of Management Science and Real Estate, Chongqing University, Chongqing 400045, China

Email address: gwliu@cqu.edu.cn 


\begin{abstract}
With the rapid process of urbanisation in China, the challenges facing cities with regard to urban fabric, urban function, and human living conditions are enormous. Urban renewal provides opportunities to address these challenges and realise sustainable development. This study proposes a framework for integrating an indicator evaluation system and a decision-making matrix for urban renewal at the neighbourhood level in China; the level at which most development projects take place in a city. The indicator system covers subjective and objective evaluations on different aspects of neighbourhoods to shed light on specific problems and characteristics, namely, social aspects, economic aspects, environmental aspects, land use forms, building conditions, and facility conditions. The decision-making matrix is designed to provide implementation paths and corresponding strategies for urban renewal. The proposed framework was tested using a case study of eight neighbourhoods of Qixinggang, Yuzhong District, Chongqing in China. The results show the status quo and problems of the selected neighbourhoods and specific strategies to address these are subsequently proposed. Via in-depth investigations on various neighbourhoods within a city, decision-makers are capable of locating key areas and adjusting practical approaches from a 'one size fits all' approach to ones that are customised and offer small-scale improvements. The proposed framework can shed light on other empirical cities that possess similar local characteristics.
\end{abstract}

Keywords: decision-making, neighbourhood renewal, renewal strategy, sustainability

\title{
1. Introduction
}

Urban renewal is a process in which resources are reused and urban environments are rebuilt (Peng et al., 2015; Zheng et al., 2016). This is done to resolve urban problems and bring about lasting improvements to the economic, physical, social, and environmental conditions of an area (Roberts and Sykes, 1999). With the development of urban renewal in practice and theory, the goal of urban renewal combines improvements to social welfare, business redevelopment, and other goals. Given the increasing problems that cities face, including social disintegration, economic recession, environmental pollution, and urban function deterioration, studies on urban renewal have received significant attention worldwide (e.g., Randolph and Freestone, 2012; Zheng et al., 2014; Tin and Lee, 2017; Almeida et al., 2018).

Urban renewal initiatives with invigorating aims have been proposed including; improving physical infrastructures and buildings (Peng et al., 2015), revitalizing urban economy (Musterd and Ostendorf, 2008), increasing land values (Adamsa and Hastings, 2001; Ho et al., 2012), and ameliorating environmental deterioration (Adamsa and 
Hastings, 2001; Chan and Yung, 2004). However, these initiatives sometimes lead to negative consequences, such as social exclusion and loss of community identity. This tends to disproportionately affect disadvantaged groups (McGregor and McConnachie, 1995; Yau and Chan, 2008). The New Urban Agenda and the Sustainable Development Goal 11 of the United Nations signify that sustainable development should be involved in urban renewal initiatives. A city may fail to realise its overall sustainability due to unsustainable components (Sharizfi and Murayama, 2013). This implies that sustainable development should be embraced at the local scale (Mazza and Rydin, 1997; Shi et al., 2016). Neighbourhoods, as fundamental parts of a city (Rohe, 2009), are the frontline for promoting sustainable development (Choguill, 2008). At the same time, a neighbourhood is a spatial scale at which most development projects are initiated (Sharifi and Murayama, 2013). Urban renewal initiatives at the neighbourhood level can contribute to sustainable development if they are implemented properly.

China has undergone unprecedented urbanisation over the last three decades with an annual increase rate of $2.86 \%$. This has caused severe urban problems. Unprecedented massive rural-to-urban migration and rapid economic growth have resulted in an immense increase in urban built-up areas and an extension to urban boundaries (Zhang et al., 2018; Yu et al., 2014). Such expansions often occupy green land and cultivated land. Moreover, urban land cannot be infinitely expanded due to financial and infrastructure constraints as well as the natural conditions that exist in urban fringe areas (Liu et al., 2016; Liu et al., 2019). Arable land has decreased by 7.3 million ha while built-up land has increased from 36.4 million ha to 39.1 million ha between 2001 and 2017. As a country with a large population and little per capita land, China should place a greater emphasis on the strategic use of land and reinforce the protection of cultivated land. The reuse of existing land through different urban renewal strategies can address the scarcity of land resources, and this will also provide opportunities for sustainable urbanisation. Urban renewal has, therefore, caught the attention of scholars in relevant disciplines and became a major element of consideration with regard to implementing urban policies in China.

To ensure the feasibility and applicability of urban renewal strategies, plenty of studies focusing on measuring sustainability have been conducted (e.g., Glasson and Wood, 2009; Boggia and Cortina, 2010; Almeida et al., 2018). The indicator-based approach has been widely used for assessing sustainable urban renewal before implementation. In addition to assessing the potential of urban renewal, the indicator-based approach can be adopted to evaluate the impacts of urban renewal initiatives after implementation (e.g., Hemphill et al., 2004; Williams and Dair, 2007; Glasson and Wood, 2009). Social, ecologic, and economic aspects are regarded as common principles of urban renewal 
assessment given that urban renewal is consistent with sustainable development in terms of social, ecologic, and economic sustainability (e.g., Zheng et al., 2017; Wang et al., 2014; Tanguay et al., 2010; Yang, 2017). As urban sustainability should be discussed with reference to different local contexts, specific categories such as integrated regional benefits (Hemphill et al., 2004; Yang, 2017), land use (Hemphill et al., 2004, Wang et al., 2014), and resources use (Hemphill et al., 2004; Almeida et al., 2018) have to be proposed.

Though a vast body of existent literature about urban renewal decision-making has been conducted, some research gaps still exist. Firstly, studies tend to focus on the city scale (e.g., Manupati et al., 2018; Yi et al., 2017; Farid, 2011; Munier, 2011) or the individual building scale (e.g., Ho et al., 2012; Wang et al., 2014; Salinas Varela and Baeriswyl Rada, 2017) rather than the neighbourhood level. Urban renewal initiatives at the neighbourhood level can be planned in terms of the local context within which it operates and in which it is a part (Luke et al., 2018; Riera et al., 2018), and at the same time are able to reflect the sustainability vision at the city level. Furthermore, there is a distinctive lack of studies on urban renewal decision-making at the neighbourhood level under the Chinese context. Secondly, the final goal of neighbourhood renewal is to ensure that local residents are willing to live and work in the neighbourhood in the long term. Thus, implementing people- and place-based strategies is crucial (McDonald et al., 2009). As an important factor affecting the effectiveness of strategy implementation, residents' perceptions of their residential neighbourhoods play a core role in determining how urban renewal initiatives should be conducted. However, the existent assessment does not well address local preferences and location-specific responses (Dogruyol \& Arayici, 2018; Mateo \& Cuñat, 2016). The conflicts between the government's top-down planning approach and residents' appeals are major barriers to impeding effective implementation of urban renewal strategies. Thirdly, existing strategies and practical methods for urban renewal tend to be general and lack specific guidance for implementation. For instance, many studies such as those by Mehdipanah et al. (2013) and Tin and Lee (2017) suggest that improving infrastructure conditions is an efficient way to achieve urban renewal. However, such studies failed to provide detailed approaches for implementation, such as quantity or quality improvement. Fourthly, most studies on strategies for sustainable urban renewal tend to be rigid and inflexible, which points to a specific type of development. The implementation of urban renewal should be in conformity to the local context and be flexible to adapt to different scenarios. An adaptive framework with multiple alternative strategies and practical methods is required for urban renewal decision-making and implementation.

The purpose of this study is to propose an adaptive decision-making framework for 
urban renewal at the neighbourhood scale in China, in which the current status of neighbourhoods and associated strategies can be identified. Based on human-centred and place-based principles, an indicator system that captures the top-down and the bottom-up analyses is included in the framework. After a comprehensive evaluation of sustainability and physical conditions, a strategy matrix detailing working paths and renewal strategies for the dynamic urban renewal process is developed. The specific working path can proffer efficient urban renewal strategies under different scenarios. To illustrate and validate the framework, a case study of Qixinggang, Yuzhong District, Chongqing in China was used. Against the severe urban decay issue and the policy agenda of 'ecological restoration and urban rehabilitation' in Chongqing, the case study can provide valuable decision-making references. Furthermore, the proposed framework aims at providing detailed strategies and paths for decision-making. The case study area can reveal whether neighbourhoods within close geographical proximities should adopt the same renewal strategy. The data were collected from multiple sources, including questionnaire surveys, field visits, and official statistical data. The findings can inform decision-makers to locate key areas and adopt customised approaches in the implementation process.

The remainder of this paper is organised as follows: Section Two review the literature on decision-making support for urban renewal. Section Three presents the conceptual framework with details. Thereafter, an introduction to the case study area is provided in Section Four. Section Five unpacks the current issues faced by the selected 'casestudy' neighbourhoods. Section Six explains the implementation paths, and the associated strategies and practical methods for urban renewal at the neighbourhood level. The last section is a conclusion and additionally provides recommendations for future research.

\section{Urban renewal decision-making}

\subsection{Decision-making support for urban renewal}

Urban decay and the deterioration of urban living conditions have raised concerns on urban renewal from both decision-makers and researchers. Urban renewal provides opportunities to address various challenges such as urban decay, social inequality, and environmental pollution in cities and realise sustainable development. As various issues and spatial scales are involved in urban renewal initiatives, the urban renewal decisionmaking process becomes complicated (Zheng et al., 2017; Peng et al., 2015). A large body of studies has been conducted to examine how to improve the decision making of urban renewal.

It has been acknowledged that early, continuous, and cautious evaluation of urban 
renewal initiatives can ensure the timely improvement of existing programmes (Hemphill et al., 2004). Among existing studies, there has been one rich strand of research on the development of decision support models. For example, Almeida et al. (2018) developed a sustainability assessment modal to support rehabilitation actions after comparing three assessment systems. Considering the urban renewal process as dynamic, Peng et al. (2015) proposed a decision support model to monitor urban renewal; Fuzzy set theory and Monte Carlo simulation were applied to solicit critical measurement indicators. To identify dilapidated buildings, the Dilapidation Index was developed to assess the present situation of local private residential buildings and the potential of urban renewal in the decision-making process (Ho et al., 2012). By adhering to the multi-scalar nature of urban renewal, a multi-scale model was proposed by Zheng et al. (2017) to support decision making at the city, district, and neighbourhood levels.

It is widely accepted that evaluation can provide information about current issues and predict future trends, which may facilitate proposing appropriate strategies (Hiremath et al., 2013; Hemphill et al., 2004). Many studies, rather than developing decision support models, focus on evaluating current conditions and proposing strategies accordingly by using the indicator-based approach ranging from a composite index to a more comprehensive indicator system (Kamble and Bahadure, 2019). For example, the Index of Multiple Deprivation in the UK, with the emphasis on economic dimensions of deprivation, has been adopted to identify the area in need of regeneration (Greig et al., 2010). By using the case of Changzhou, China, Yang (2017) proposed a comprehensive assessment system that combines the socio-economic, environmental, and regional development to work out appropriate strategies for the renewal of old industrial areas. Due to the diversification, the process of selecting a set of robust and effective indicators is complex and challenging. Objectivity, independence, measurability, accessibility, and relative stability have been regarded as the basic principles required in the selection process ( $\mathrm{Li}$ et al., 2009; Hiremath et al., 2013; Yang, 2017). Meanwhile, indicator development according to local characteristics has been increasingly emphasised (e.g., Li et al., 2009; Sharifi and Murayama, 2013; Tin and Lee, 2017).

Different renewal strategies have been proposed to meet various objectives. At the city or district scale, maximising the macro-level benefits for the whole by balancing social, economic, environmental development is the tendency (McDonald et al., 2009; Moussiopoulos et al., 2010; Peng et al., 2015). At the building scale, studies focus on physical improvement (Ho et al., 2012). Investigations at the city-level have the weakness of being unable to gain specific results for implementation while building- 
level investigations may fail to differentiate intra-connections and functions at the higher levels. Urban renewal initiatives at the neighbourhood level, where policies and detailed plans can be implemented, can contribute to sustainable development with concerns on intra-connections (Musterd and Ostendorf, 2008).

Studies on urban renewal at different scales and in various contexts have been conducted. As the frontline for promoting sustainable urban development, urban renewal at the neighbourhood scale has increasingly been concerned. However, limited research on sustainable renewal assessment and strategies at the neighbourhood scale has been conducted, especially in the Chinese context. Table 1 summarises recent studies on the decision-making for sustainable neighbourhood renewal. Social, ecologic, and economic sustainability are regarded as common principles of neighbourhood renewal assessment. Other specific categories (e.g., building performance) have gained attention recently to make the assessment more comprehensive and useful (Wang et al., 2014; Tin \& Lee, 2017). Additionally, to capture what makes a sustainable neighbourhood for its residents and guarantee the completion of a project from its preevaluation to implementation (Luke et al., 2018), local preferences about different aspects of a neighbourhood should not be ignored. Currently, quantitative indicators have been widely applied in the assessment. Qualitative information including sense of place, social cohesion, and well-being, however, has not been well addressed. Even though most studies provide clear outcomes for renewal, strategies and frameworks are not adaptable for different types of neighbourhoods. Furthermore, neighbourhoods are continuously changing. There is a need to develop an adaptive decision-making framework with different strategies that can respond to different scenarios. In China, a series of policies have been released to promote sustainable urban renewal. To promote effective implementation, it is essential to develop practical approaches with implementation details. Thus, a dynamic decision-making process that can provide different strategies and practical approaches for various scenarios and echo to local responses is of importance. 
Table 1. Studies on recent decision-making for sustainable neighbourhood renewal.

\begin{tabular}{|c|c|c|c|c|c|}
\hline Theme & Dimension & Indicator nature & Strategic management & Country/Region & Author(s) \\
\hline Development of neighbourhood renewal & $\begin{array}{l}\text { Physical environment } \\
\text { Environmental physics } \\
\text { Socio-cultural }\end{array}$ & quantitative & General, static & Malaysia & $\begin{array}{l}\text { (Tin \& Lee, } \\
\text { 2017) }\end{array}$ \\
\hline $\begin{array}{l}\text { Neighborhood sustainability in urban } \\
\text { renewal: An assessment framework }\end{array}$ & $\begin{array}{l}\text { Social } \\
\text { Economic } \\
\text { Environmental } \\
\text { Building condition }\end{array}$ & quantitative & General, static & Hong Kong, China & $\begin{array}{l}\text { (Zheng et } \\
\text { al., 2016) }\end{array}$ \\
\hline $\begin{array}{l}\text { Fostering sustainable urban renewal at the } \\
\text { neighborhood scale }\end{array}$ & $\begin{array}{l}\text { Social } \\
\text { Economic } \\
\text { Environmental }\end{array}$ & quantitative and qualitative & Not mentioned & Switzerland & $\begin{array}{l}\text { (Riera \& } \\
\text { Rey, 2018) }\end{array}$ \\
\hline $\begin{array}{l}\text { Urban regeneration for sustainable } \\
\text { communities }\end{array}$ & $\begin{array}{l}\text { Social \& Cultural } \\
\text { Economy } \\
\text { Environmental } \\
\text { Housing \& Built environment }\end{array}$ & quantitative and qualitative & General, static & The UK & $\begin{array}{l}\text { (McDonald } \\
\text { \& Malienè, } \\
\text { 2009) }\end{array}$ \\
\hline $\begin{array}{l}\text { Integrated sustainability assessment and } \\
\text { renewal of old industrial areas }\end{array}$ & $\begin{array}{l}\text { Ecological Environment } \\
\text { Economic development } \\
\text { Socio-cultural benefits } \\
\text { Integrated regional benefits }\end{array}$ & quantitative and qualitative & Specific, static & Changzhou, China & $\begin{array}{l}\text { (Yang, } \\
\text { 2017) }\end{array}$ \\
\hline $\begin{array}{l}\text { An alternative model for measuring the } \\
\text { sustainability of urban regeneration }\end{array}$ & $\begin{array}{l}\text { Building performance } \\
\text { Environmental development } \\
\text { Social development }\end{array}$ & quantitative & General, dynamic & l & $\begin{array}{l}\text { (Peng et } \\
\text { al., 2015) }\end{array}$ \\
\hline
\end{tabular}




\section{Economic development}

Decision support for sustainable urban

renewal

\section{Economic}

\section{Environmental}

Building condition

Note: 'General' means that urban renewal strategies mentioned in the article tend to be one-size-fits-all and lack specific guidance for implementation, which is contrary to what 'specific' means. 'Static' means that urban renewal strategies are made based on the current performance of a neighbourhood, but are not adaptable to changes in the neighbourhood over time, which is contrary to what the 'dynamic' means. 


\subsection{Important considerations of urban renewal decision-making}

Even urban renewal activities always possessed inspiring objectives, many of them received criticism, such as loss of local characteristics, relocation of local residents, and social segregation (Rohe, 2009). Human-centred and place-based approaches can provide opportunities to address local problems, which are thus crucial for deciding urban renewal strategies (McDonald et al., 2009; Donaldson and Du Plessis, 2013). As an important factor affecting the effective implementation of neighbourhood renewal strategy, residents' perceptions and preferences play a core role in determining the direction that neighbourhood renewal activities may lead to. The highly intertwined and complex relationships between residents and neighbourhood matter greatly to the sustainability of a neighbourhood. On the one hand, a neighbourhood's form and current conditions directly affect residents' daily life and behaviours. On the other hand, residents' preferences and behaviours contribute to the sustainability of a neighbourhood. Therefore, community participation, which can involve residents' voices, needs to be emphasised in neighbourhood renewal processes (Navratil et al., 2018).

Area-based approaches enjoy popularity in urban renewal and spatial policies in many countries, such as the UK, Northern Ireland, and South Africa. Since areas within cities suffering from multiple disadvantages, area-based approaches should be proposed to appropriately address problems in a target area based on local characteristics (Donaldson and Du Plessis, 2013). Main themes from existing literature on place-based principles and urban renewal pertain to proposing relevant strategies (e.g., Yang, 2017), evaluating the impacts of area-based renewal policies (e.g., Mohan et al., 2018), and exploring the implementation of area-based renewal projects (e.g., Donaldson and Du Plessis, 2013).

Building on human-centred and placed-based principles in determining urban renewal strategies, specific guidance can be proposed to improve the effectiveness of strategy implementation (Mehdipanah et al., 2013). General policies and strategies may fail to locate outstanding areas and meet local needs in the urban renewal process (Bromley et al., 2005). The same renewal strategy may be not appropriate for neighbourhoods with close geographical locations. Placed-based and specific approaches can directly make contributions to the sustainability of a neighbourhood as the strategies are more effective with details by considering local contexts when details and local contexts are considered (Bromley et al., 2005). Furthermore, strategies to improve the quality of public services for a better quality of life are particularly important in the long term (Lucas et al., 2004). Urban renewal decision-making must take the principles mentioned above into account. 


\section{Conceptual framework}

This study proposes a framework for integrating an indicator evaluation system and a decision-making matrix. By using the indicator system, a detailed assessment of the local condition will be conducted. Drawing on the assessment results, dynamic strategies and paths will be proposed via the decision-making matrix. In terms of different practical approaches associated with renewal strategies, area- and peoplebased principles will be adopted to identify potential practical approaches corresponding to the local context and specific objectives.

Several research methods were adopted to develop the proposed framework, including a literature review, expert interviews, and a case study. The literature review was employed to identify initial indicators assessing current conditions of neighbourhoods and to design the decision-making matrix. Expert interviews were undertaken to adjust the indicator system and improve the initial decision-making matrix. Finally, the proposed framework was applied to assess renewal neighbourhoods in the case study area for an illustration purpose.

\subsection{Development of the indicator system}

Drawing on existent literature that focuses on measuring urban renewal performances and assessing neighbourhood sustainability, a draft list of indicators was firstly constructed. Social, economic, and environmental sustainability are regarded as common principles when it comes to measuring the performance of urban renewal programmes. Given the local context of Chongqing, as well as the results of expert interviews, a modified indicator system was proposed to assess current sustainability levels and physical conditions of different neighbourhoods. As a mountainous city, Chongqing is one typical densely-populated city in the world. With the ever-increasing population and limited land supply, Chongqing has been striving to place a greater emphasis on the strategic use of land. In addition, Chongqing is facing a formidable problem of inadequate neighbourhood facilities, urban decay, and dilapidation. Like many first-tier cities in China such as Shanghai, Shenzhen, and Guangzhou, Chongqing has proposed renewal plans for old urban areas, in which nearly 120,000 shantytowns are expected to renewal in 2019-2020 (Wang and Xiang, 2019). Land form and urban function affect the healthy and sustainable development of Chongqing. Thus, the indicator system specifically takes physical conditions and land use form into consideration. This indicator system also includes qualitative indicators and indicators representing location-specific responses from local residents to capture local characteristics, local preferences, and residents' perceptions. Figure 1 shows the procedure of developing the indicator system. 
Stage 1: Literature review

Identify indicators evaluating sustainable neighbourhood renewal

Stage 2: System innovation

Area- and people- based principles

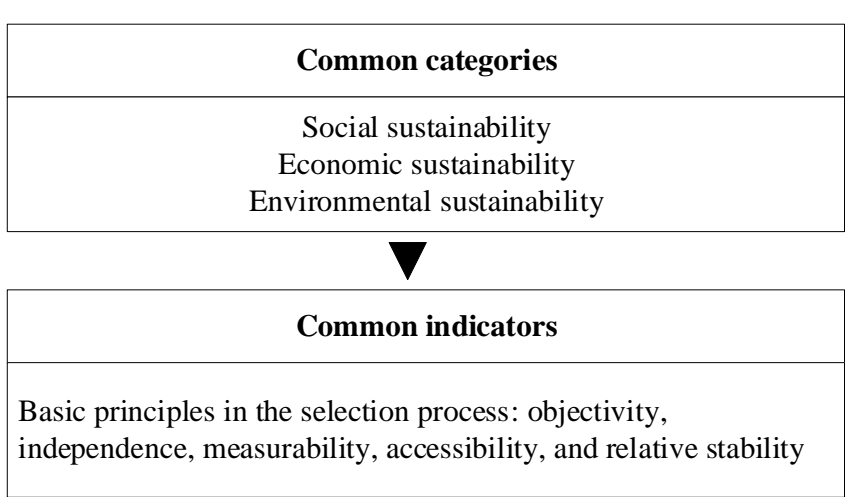

\begin{tabular}{|l|}
\hline \multicolumn{1}{|c|}{ Local categories } \\
\hline Local context: urban function, spatial structure, land form... \\
Physical conditions (buildings and facilities) \\
Land use form
\end{tabular}

\begin{tabular}{|c|}
\hline Specific indicators \\
\hline $\begin{array}{l}\text { Considerations when adapting the indicator system: } \\
\text { local characteristics, local preferences, and residents' perceptions }\end{array}$ \\
\hline $\begin{array}{l}\text { Qualitative indicators (e.g. sense of neighbourhood) } \\
\text { Location-specific responses } \\
\text { (e.g. density of small businesses with local characteristic) }\end{array}$ \\
\hline
\end{tabular}

Figure 1. The procedure of the indicator system development

In general, to determine the status quo of targeted neighbourhoods, the proposed indicator system covers two dimensions including neighbourhood sustainability and physical condition; both subjective and objective evaluations on different aspects of neighbourhoods were conducted by using data from multiple sources (Appendix A). The sustainability level for each neighbourhood was evaluated from four categories of social, economic, environmental, and land use aspects. The physical condition for a neighbourhood was divided into building and facility conditions.

Given the lack of comparability between different indicators due to the diversity of the units, each indicator is required to be standardised. This study employed formulas by Zheng et al. (2017) to distinguish the positive and negative impacts of various indicators on the overall values of physical conditions and sustainability. This can be expressed as follows:

Negative indicator: $\mathrm{y}_{i j}=\left(\max x_{i j}-x_{i j}\right) /\left(\max x_{i j}-\min x_{i j}\right)(1 \leq i \leq m, 1 \leq j \leq n)$ 
Positive indicator: $\mathrm{y}_{i j}=\left(x_{i j}-\min x_{i j}\right) /\left(\max x_{i j}-\min x_{i j}\right)(1 \leq i \leq m, 1 \leq j \leq n)$

Table 2 displays illustrative examples of standardising a positive indicator and a negative indicator. After the standardization of indicator values, the overall score relating to the physical condition of a neighbourhood was the sum of the score of building condition and that of facility condition. The overall score of sustainability of a neighbourhood was the sum of the scores of its four sustainability categories, namely the social aspect, economic aspect, environmental aspect, and land use form.

Table 2. Illustrative examples of standardising different types of indicators.

\begin{tabular}{ccllllllll}
\hline & $\mathrm{X} 1$ & $\mathrm{X} 2$ & $\mathrm{X} 3$ & $\mathrm{X} 4$ & $\mathrm{X} 5$ & $\min x_{i j}$ & $\max x_{i j}$ & $\max x_{i j}-\min x_{i j}$ \\
\hline Negative & measurement & 2 & 3 & 5 & 4 & 1 & 1 & 5 & 4 \\
indicator & & & & & & & & & \\
& $\mathrm{y}_{\mathrm{ij}}$ & 0.75 & 0.50 & 0 & 0.25 & 1 & $/$ & $/$ & $/$ \\
Positive & measurement & 0.80 & 0.40 & 0.60 & 0.20 & 0.50 & 0.20 & 0.80 & 0.60 \\
indicator & & & & & & & & & \\
& $\mathrm{y}_{\mathrm{ij}}$ & 0 & 0.33 & 0.67 & 1 & 0.50 & $/$ & $/$ & $/$ \\
\hline
\end{tabular}

Note: The data is fictional.

\subsection{The development of a decision-making matrix}

This study employed a decision-making matrix comprising four quadrants to present the various physical condition and sustainability levels that were recorded. In this matrix (Figure 2), six critical paths were elaborately designed to facilitate the implementation of urban renewal strategies at the neighbourhood level. Given that issues of sustainability and physical conditions are core issues for policy-making and construction practice of urban renewal (Bromley et al., 2005; Zheng et al., 2016), neighbourhoods that possess different levels of sustainability and/or physical conditions need to select specific strategies and paths in light of people- and area-based principles. The strategies corresponding to implementing paths are proposed based on roles of different strategies as well as sustainability levels and physical conditions of neighbourhoods. 


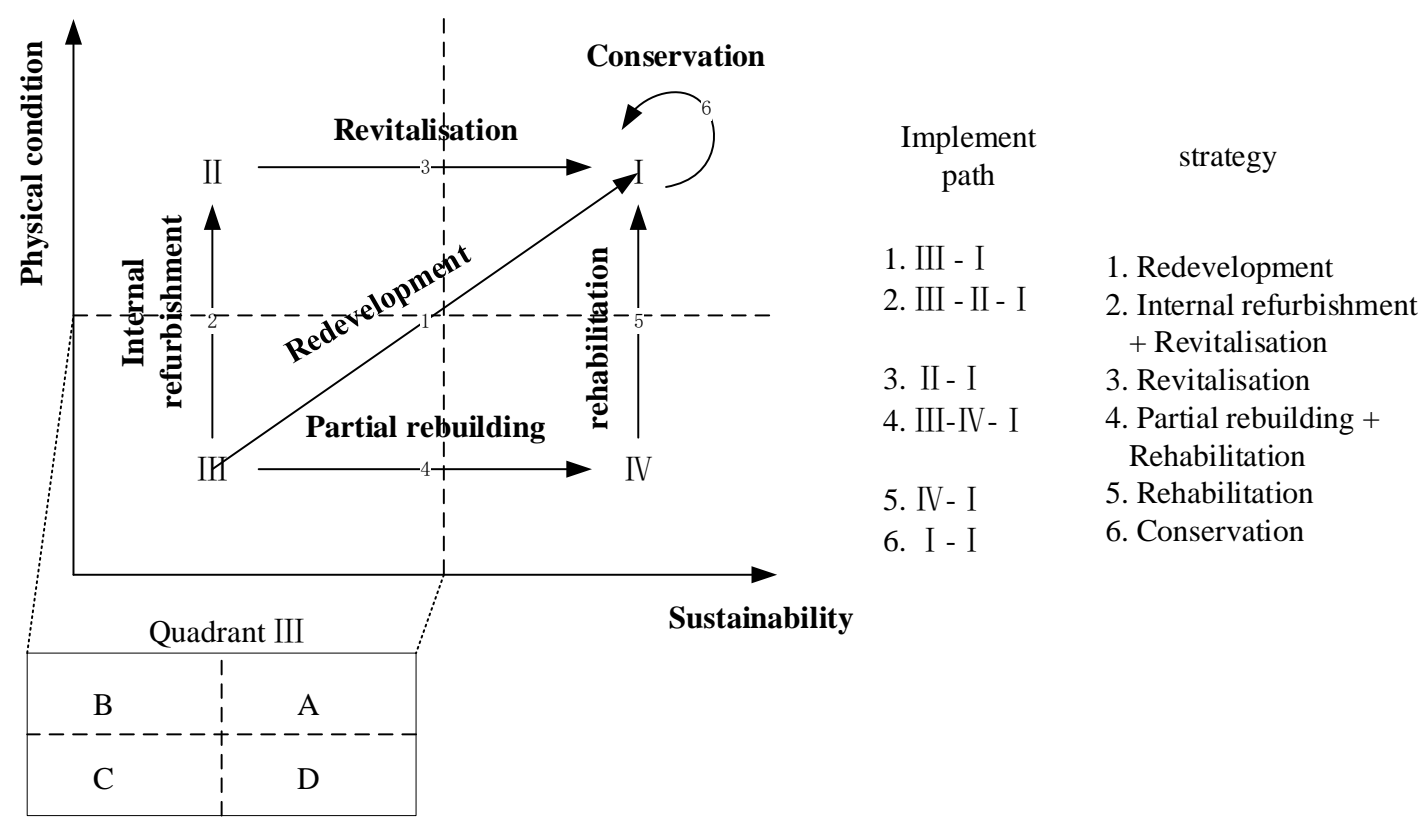

Figure 2. Decision-making matrix for urban renewal

In quadrant I, both sustainability and physical conditions have high values. This indicates that there is limited room for further improvement. It follows that a conservation strategy (i.e., I-I, the sixth path) should be implemented to prevent decay.

Quadrant II includes neighbourhoods with low values of sustainability but high physical condition values. Such neighbourhoods should regard revitalisation strategies (i.e., II-I, the third path) as the way, which focus on incorporating the 'place-making' concept and respecting local characteristics to create vital neighbourhood atmospheres.

Quadrant IV represents the inverse situation of quadrant II. This, therefore, implies that rehabilitation strategies (i.e., IV-I, the fifth path) should be adopted. Such strategies are subject to improving physical conditions in-situ, prolonging the lifespan of buildings, and slowing down the pace of urban decay.

The situation that exists in quadrant III is such that the neighbourhoods possess both poor physical conditions and low sustainability levels. As a consequence, multiple strategies (III-I; III-II-I; III-IV-I) could be implemented to achieve renewal goals. When both values are extremely low (the region $\mathrm{C}$ in the quadrant III), there is an urgent need to implement a redevelopment strategy (e.g., III-I, the first path) so as to build a new environment.

Conversely, region A exhibits comparatively higher values of sustainability and physical condition. Neighbourhoods within this region could either implement internal 
refurbishment in a strategy akin to that in the second path (e.g., III-II) or partially rebuild as in the fourth path (e.g., III-IV) to ensure effective urban renewal. The selection of specific strategies is dependent on detailed factors, such as the preference of residents, finance, and the feasibility of resettling residents.

In region $\mathrm{B}$, improving sustainability is the most important priority during the urban renewal process. The strategy of partial rebuilding (e.g., III-IV) can be adopted in advance to enhance sustainability, followed by rehabilitating buildings and facilities that are in a repairable state (e.g., IV-I). The whole process prioritises the benefits of both decision-makers and local residents by avoiding involving tricky issues including resettlement of a wide swath of residents and the issue of huge investment in a short time (Yau and Chan, 2008).

Conversely, neighbourhoods in region D can implement a two-step strategy with the sequence from internal refurbishment (e.g., III-II) to revitalisation (e.g., II-I). Such actions can both meet the needs of urban renewal by addressing physical decay problems and save economic costs because there is no need to undertake large-scale reconstruction activities.

Based on the indicator evaluation system and the decision-making matrix, a framework (see Figure 3) for urban renewal decision making is proposed, which provides information about the indicator assessment results and implementation paths. Given that different practical approaches have particular focuses, details of strategies and potential practical approaches are showed in Table 4 in the sixth section.
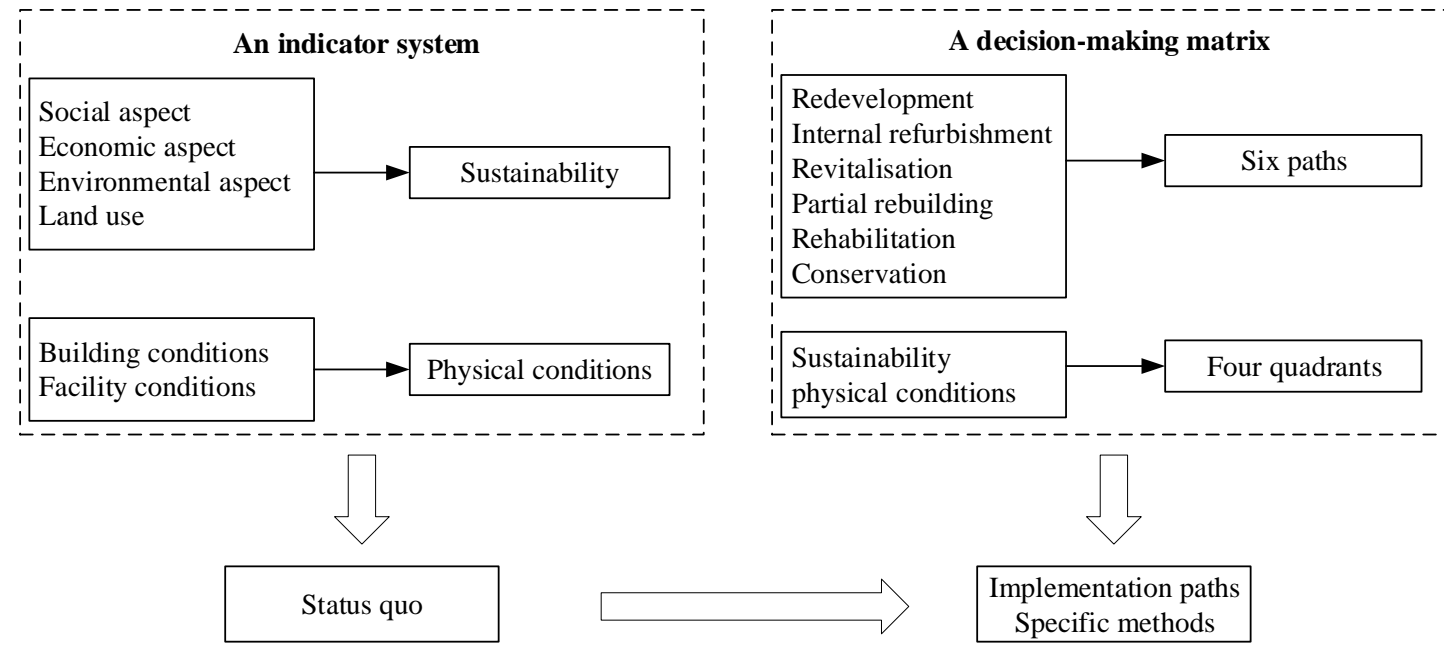

Figure 3. The proposed framework of neighbourhood renewal decision making

\section{Case study}




\subsection{Study area}

Chongqing is located in southwest China and has a population of 30.75 million. Encompassing 82,400 square kilometres, mountainous areas account for $76 \%$ of this landmass. Continually facing infrastructure shortages, land supply shortages, environmental pollution, and urban decay, Chongqing launched an action plan in 2017 entitled: ecological restoration and urban rehabilitation. The purpose of this action plan was to solve urban diseases and improve the living environment. Although some urban renewal programs have taken place in Yuzhong district (one of the nine major urban districts in Chongqing) since 2007, the publication of 'Urban Renewal Planning for Qixinggang Street' in 2017 and the convening of a symposium on ecological restoration and urban rehabilitation in 2018 by Yuzhong district signify that urban renewal remains an agenda upon which the government is focused. Research on urban renewal within this district is of great value to decision-makers. Qixinggang comprising eight neighbourhoods in Yuzhong district was selected as the case study area for this study. Yuzhong district which is the financial, business, and cultural centre of Chongqing, has a land area of 20.08 square kilometres and a resident population of 659,000 . The case study (Figure 4) is the first project to reveal whether neighbourhoods within close geographical proximities should adopt the same renewal strategy. Table 3 provides a basic profile of the eight neighbourhoods.

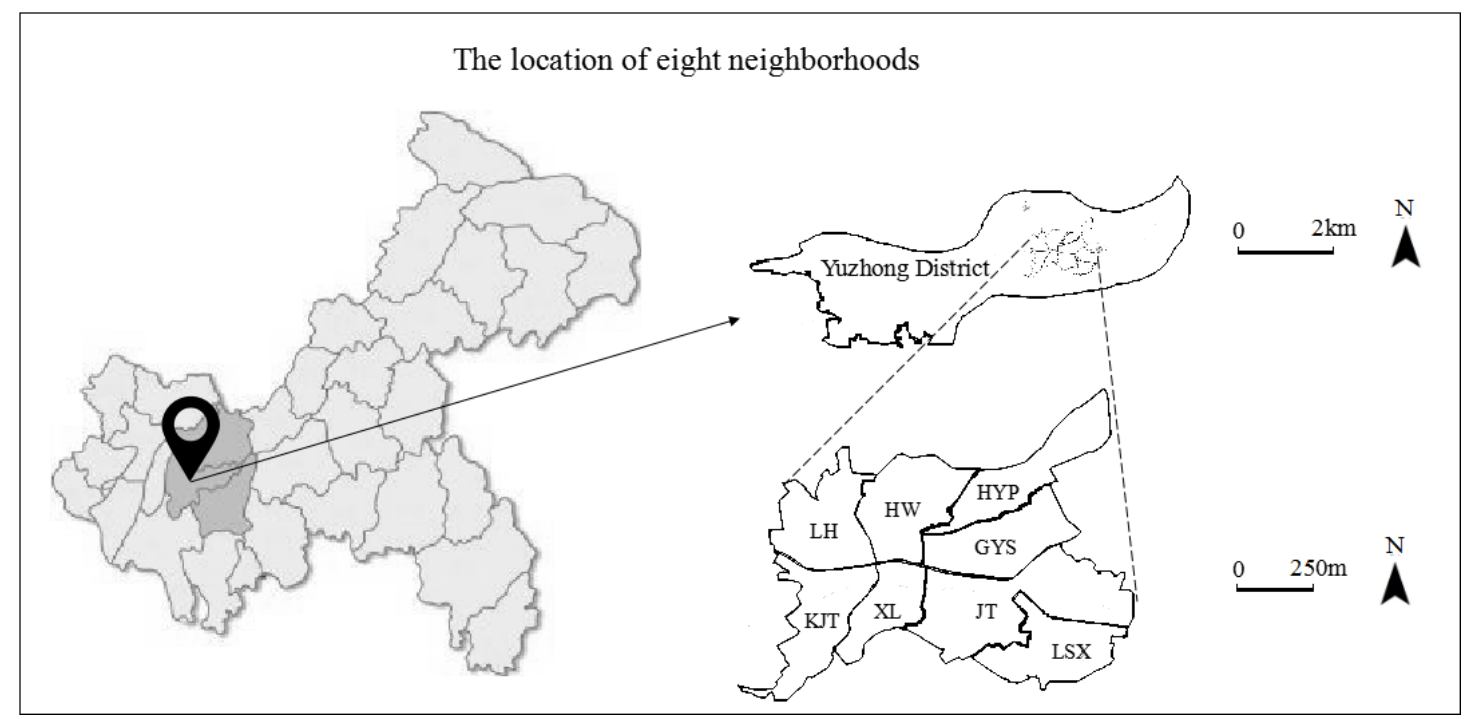

Figure 4. Location of eight neighbourhoods in Qixinggang, Yuzhong District, Chongqing, China

Table 3. Pen pictures of eight neighbourhoods

$\begin{array}{llll}\text { Abbrev } & \text { Land area } & \text { Resident } & \text { Number of Characteristics } \\ \text {-iation } & \left(\mathrm{km}_{2}\right) & \text { population } & \text { residential } \\ & & & \text { buildings }\end{array}$




\begin{tabular}{|c|c|c|c|c|c|}
\hline $\begin{array}{l}\text { Kangjiantang } \\
\text { Neighbourhood }\end{array}$ & KJT & 0.100 & 11123 & 88 & $\begin{array}{l}\text { Close to Pipashan Park; } \\
\text { possesses rich cultural } \\
\text { resources }\end{array}$ \\
\hline $\begin{array}{l}\text { Xinglongjie } \\
\text { Neighbourhood }\end{array}$ & $\mathrm{XL}$ & 0.043 & 2232 & 32 & $\begin{array}{l}\text { Has a floating population and } \\
\text { plenty of neighbourhood } \\
\text { activities }\end{array}$ \\
\hline $\begin{array}{l}\text { Jintangjie } \\
\text { Neighbourhood }\end{array}$ & $\mathrm{JT}$ & 0.161 & 10680 & 53 & $\begin{array}{l}\text { The location of many } \\
\text { autonomous organizations and } \\
\text { government organizations }\end{array}$ \\
\hline $\begin{array}{l}\text { Lingshixiang } \\
\text { Neighbourhood }\end{array}$ & LSX & 0.060 & 7530 & 36 & $\begin{array}{l}\text { The location of the Yuzhong } \\
\text { District Government; close to } \\
\text { Tongyuanmen City-wall Park }\end{array}$ \\
\hline $\begin{array}{l}\text { Guiyuansi } \\
\text { Neighbourhood }\end{array}$ & GYS & 0.105 & 9248 & 26 & $\begin{array}{l}\text { Has an old temple and many } \\
\text { activity rooms }\end{array}$ \\
\hline $\begin{array}{l}\text { Huayipo } \\
\text { Neighbourhood }\end{array}$ & HYP & 0.080 & 11047 & 35 & $\begin{array}{l}\text { An open residential area; no } \\
\text { elevator for } 86 \% \text { of buildings }\end{array}$ \\
\hline $\begin{array}{l}\text { Hanweilu } \\
\text { Neighbourhood }\end{array}$ & HW & 0.169 & 14730 & 108 & $\begin{array}{l}\text { Has the largest population } \\
\text { among the eight } \\
\text { neighbourhoods; has schools } \\
\text { and hospitals }\end{array}$ \\
\hline $\begin{array}{l}\text { Linhualu } \\
\text { Neighbourhood }\end{array}$ & LH & 0.200 & 8430 & 43 & $\begin{array}{l}\text { Has many social units and } \\
\text { prosperous businesses }\end{array}$ \\
\hline
\end{tabular}

\subsection{Data preparation}

The data required for this research included spatial data and non-spatial data. The spatial data consisted of the spatial locations of different types of infrastructure, a road network map, and a land utilisation map. The infrastructure locations and road networks were extracted from Gaode Map by a big data mining approach. The land utilisation map was digitalised to understand indicators reflecting land use form. Non-spatial data came from a questionnaire survey, a field survey, and statistical data. Statistical data was collected from the Chongqing Statistical Yearbook 2017, Water Resources Bulletins 2017, and Environmental Status Bulletins 2017. Both field survey and questionnaire survey were conducted between January to February in 2018. Field surveys were conducted to observe the current conditions and characteristics of each neighbourhood and to obtain information that is unavailable in official public data, like the diversity of public transport and parking spaces shown in Appendix A. 
To collect more detailed information on residents' perceptions, a survey via semistructured questionnaires was conducted. The first section was established to collect residents' demographic information (e.g., age, sex, education, income). The second section was prepared to obtain residents' satisfaction with different aspects of the neighbourhoods (e.g., public facilities, living environment) in a five-point Likert scale (see Appendix B). The total population size of the selected neighbourhoods is 75,020 . To ensure the robustness of the sample size, a $0.5 \%$ sample size (375 participants) were determined. By building a 5\% attrition rate, a total of a survey sample of 394 was finally decided. The questionnaires were randomly issued to people living in different neighbourhoods in Qixinggang via face-to-face interviews. Finally, 400 questionnaires were issued, and 374 valid questionnaires were returned (a response rate of 93.5\%). Data resources for each indicator are shown in Appendix A.

\section{The status quo of neighbourhoods}

\subsection{Overview of the neighbourhood condition}

According to Figure 5, the HYP neighbourhood ranked first with regard to sustainability with a score of 18.3, followed by the neighbourhoods of KJT and JT with scores of 17.9 and 16.6 respectively. A detailed investigation reveals that the major factors underlying these most sustainable neighbourhoods are numerous. The HYP and KJT neighbourhoods' scores were driven by environmental sustainability, whereas the JT neighbourhood took the lead in social sustainability. Regarding physical conditions, the JT neighbourhood obtained the highest score while the GYS neighbourhood had the worst physical conditions as a consequence of the poor condition of its buildings. 


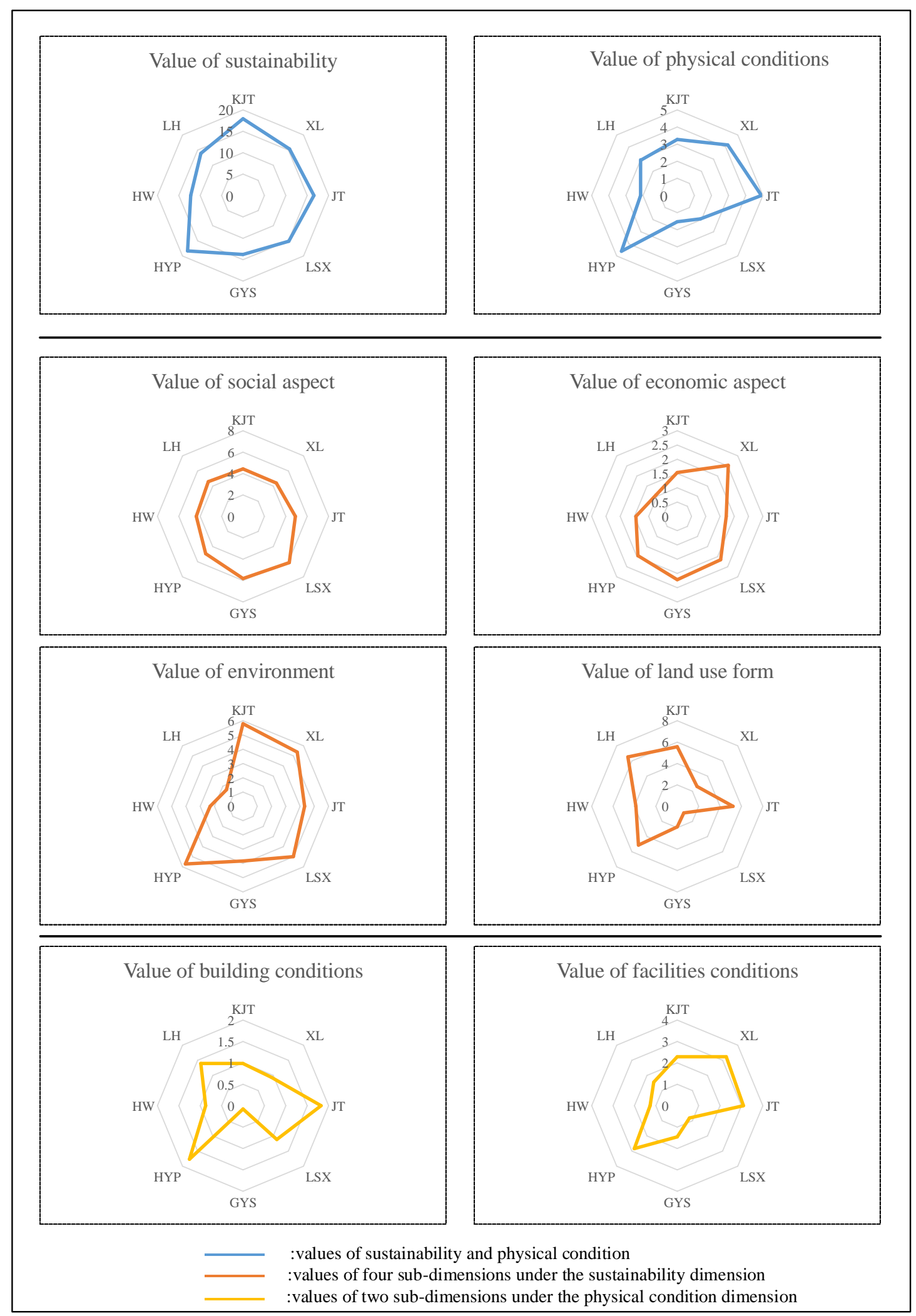

Figure 5. Values of sustainability, physical condition, and their sub-dimensions.

\subsection{Results of the top-down analysis}

Policy instruments may be misleading if policymakers only refer to the final scores obtained for different neighbourhoods. A thorough investigation into various aspects of 
a neighbourhood could result in a better understanding of the status quo. In turn, this would help them to identify specific problems in a neighbourhood, and this provides guidance for implementing urban renewal at the neighbourhood scale. Given this, the study extracted detailed information about indicator results to stimulate further discussions. As policymakers wish to maximise macro-level benefits for entire neighbourhoods it follows that the current physical condition, development situation, and function of neighbourhoods need to be paid special attention. For better illustration, detailed information pertaining to six categories (the social aspect, the economic aspect, the environmental aspect, land use form, building condition, and facility condition) were integrated into three classifications, namely, socioeconomic conditions, environmental issues, and neighbourhood functions. Figure $6(a-c)$ shows the results of the indicators when they are combined under the umbrellas of these three classifications.

Regarding the socio-economic conditions of the neighbourhoods, it can be concluded that the KJT and GYS neighbourhoods possessed more balanced development while the development of the XL and LH neighbourhoods were relatively unbalanced (Figure 5). XL neighbourhood had the highest score regarding economic aspects but ranked behind most neighbourhoods on social aspects. More specifically, the XL neighbourhood with a high population density obtained low values in the health aspect and with regard to the condition of facilities (Figure 6-a). This suggests that residents living in this neighbourhood had limited access to public resources, such as health care facilities and green infrastructure. Moreover, given the comparatively high unemployment rate and relatively low average personal income level of the LH neighbourhood (Figure 6-a), it can be suggested that the LH neighbourhood may suffer from the segregation of low-income groups - a situation which may cause some social instability.

Echoing to the New Urban Agenda and the Sustainable Development Goal 11 of the United Nations, policy-makers need to transfer their focus from economy-led development into sustainability-oriented urbanisation. It follows from this that environmental improvement plays a dominant role in maximising the macro-level benefits enjoyed by neighbourhoods. To gain an in-depth understanding of environmental status, the existent situation pertaining to resource and pollution conditions are displayed herein. According to Figure 6-b, natural resources were rich in the XL neighbourhood but scarce in the LSX neighbourhood. Conversely, and from the perspective of consumption, the LSX neighbourhood was the most resource-intensive area while the XL neighbourhood consumed the least resources. With regard to pollution, the LH neighbourhood ranked bottom in terms of noise pollution, air pollution, and waste. This may be a consequence of the two busy main roads 
surrounding it. The LH neighbourhood is the centre for commercial activities with commercial space within the neighbourhood covering more than $33.9 \%$ of its total area. With massive population flows, great efforts are required to improve the severe pollution issues experienced in this neighbourhood. Measures could include providing more green infrastructure, improving traffic systems, and increasing the number of rubbish bins.

An assessment of urban functions can reveal the strengths and weaknesses of previous planning policies and design strategies. The analysis may, in turn, provide guidance as to the policies needed to ensure a sustainable urban future. As an essential unit of urban renewal, neighbourhoods should provide basic facilities and services for a living. It is necessary to examine the current situation that exists with regard to neighbourhood functions (i.e., land use and physical conditions; see Figure 6-c). With respect to land use, the HYP neighbourhood had high densities of population, buildings, and road networks, whereas it obtained a low value for the indicator of mixed land use. This indicates that land use form within the HYP neighbourhood was comparatively uniform; residential and transportation lands were dominant. This may limit access to other public services such as shopping and entertainment, weaken the neighbourhood's vitality, and reduce the living satisfaction of residents in the area. In terms of physical conditions, the XL neighbourhood possessed two distinct features. It had more facilities in comparison to other neighbourhoods while the building condition lagged behind other neighbourhoods due to poor building maintenance.

\subsection{Results of the bottom-up analysis}

Neighbourhood renewal processes should emphasise the significance of considering residents' perceptions, as ignorance of them may lead to renewal failing to meet either residents' real needs or adequately capturing the neighbourhood-level diversities. According to the results of the questionnaire surveys, the concerns of local residents are found to be slightly different from those obtained through the top-down analysis.

\subsubsection{Living conditions}

Living conditions here include building physical conditions, infrastructure conditions, and the living environment. The opinions of local residents provided additional insights on the problems that required urgent action and this, in turn, provides guidance to policy-makers on how they can transform adverse living conditions within neighbourhoods to address the concerns of residents. The LH neighbourhood ranked behind most neighbourhoods regarding living conditions owing to local residents' dissatisfaction with the living environment and infrastructure conditions (Figure 6-d). Specifically, the satisfaction level with facilities was comparatively low, which is 
consistent with the finding from our site visit that the conditions of facilities in the LH neighbourhood were decrepit. In addition, this neighbourhood is surrounded by two busy main roads and, as a result, it suffers from server noise and air pollution. The LH neighbourhood performed worst in both objective and subjective evaluations of living conditions. Although, a positive aspect is that the LH neighbourhood ranked relatively high (the third with the score of 1.4) on the physical condition of its buildings. This result may be related to the internal refurbishments that have taken place in this neighbourhood over recent years. For the KJT neighbourhood, the subjective satisfaction with leisure facilities was the lowest whereas the objective value of accessibility to sport and leisure facilities in this area was high (Figure 6-e). This contradictory result implies that residents living in the KJT neighbourhood may be dissatisfied with the types and physical conditions of leisure facilities despite their possessing high accessibility to them. It follows, if this interpretation is correct, that priority needs to be given to improving the quality of facilities rather than increasing their quantity.

\subsubsection{Life Quality}

Residents' perspectives as to life quality offer important clues as to what a given neighbourhood is like to live in for residents and what actions need to be taken by policymakers to improve life quality therein further. The GYS neighbourhood ranked lowest regarding levels of income, education, and well-being (Figure 6-f). At the same time, however, the scores relating to socioeconomic conditions, environmental issues, and the functioning of the GYS neighbourhood were relatively high. This conflict between the top-down result and the bottom-up result illustrates that the well-built condition is not insufficiently associated with a high quality of life. The GYS neighbourhood is the main residential place for migrant workers who have limited opportunities to become formal employees due to their low education levels. Consequently, they possess less social welfare compared to local residents. 


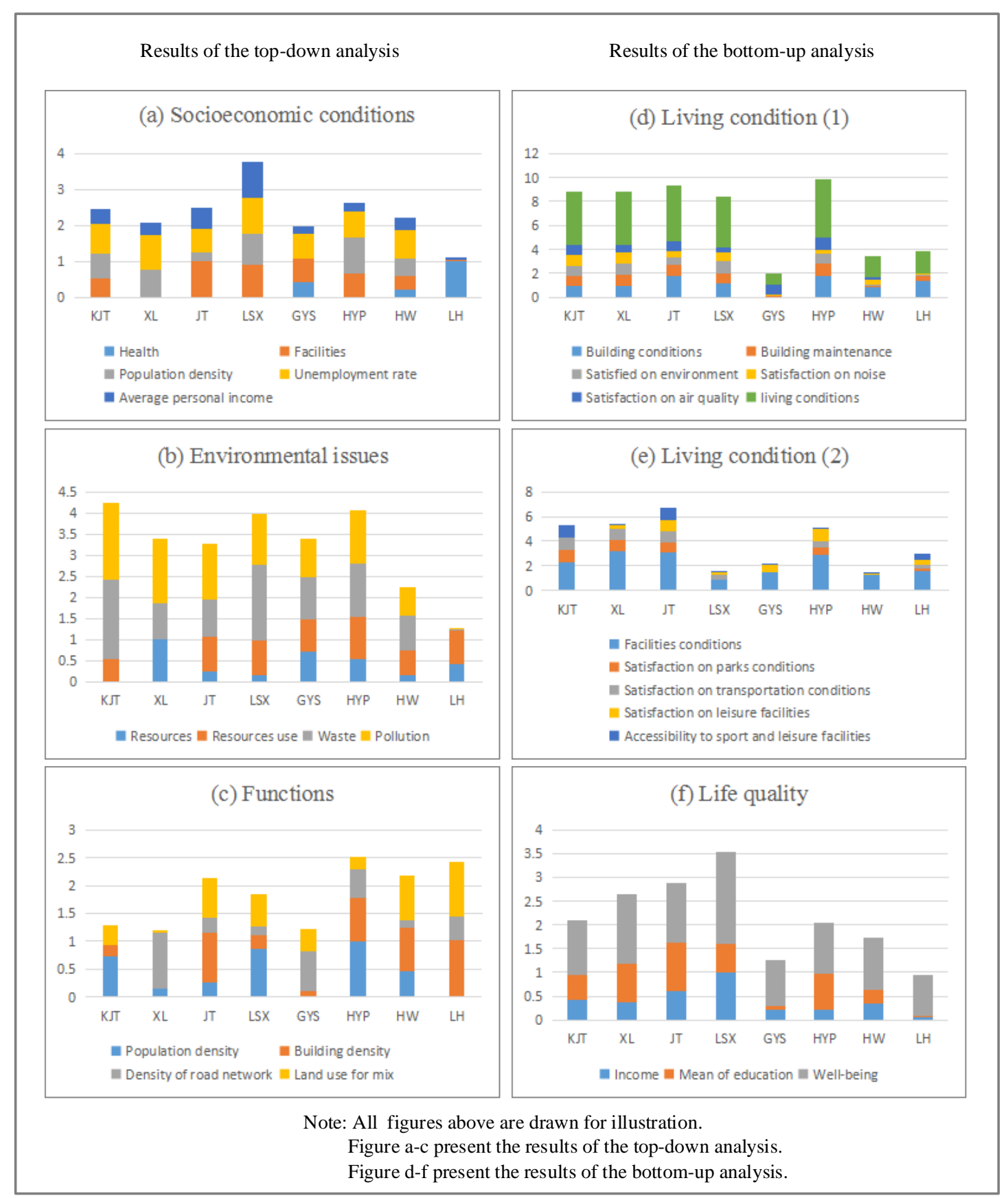

Figure 6. Scores of different indicators.

\section{Implementation strategies and methods}

The proposed decision-making matrix suggests that customised paths and strategies are required for urban renewal in practice. Based on the scores of sustainability and physical condition presented earlier, a decision-making matrix was drawn (Figure 7). Some neighbourhoods tend to adopt the same implementation strategy according to the decision-making matrix. The implementation methods of urban renewal should be flexible in real circumstances in accordance with specific characteristics of different neighbourhoods (Bromley et al., 2005; O’ Riordan, 2004). 
In quadrant I, neighbourhoods should take the conservation path to retain their high values of sustainability and physical conditions. Through scrutinising detailed problems, it is noted that residents in the KJT neighbourhood were dissatisfied with both the quality and quantity of leisure facilities that they had access to. Measures should thus be taken not only to maintain existing infrastructures, but to improve access to leisure facilities so as to improve living conditions further. Likewise, the following of a conservation strategy is suggested for the JT neighbourhood. To correspond to its own challenge, the JT neighbourhood can slightly adjust its renewal direction by encouraging the public to behave in a more environmentally sustainable way. This is particularly important given that the JT neighbourhood obtained the lowest value in waste and pollution. Similarly, the HYP neighbourhood in quadrant I also needs to adopt the conservation strategy to prevent neighbourhood decay. Given that its residents are dissatisfied with the largely uniform nature of its land use (residential and transportation), the HYP neighbourhood should increase accessibility to public facilities both within and immediately beyond its frontiers.

The XL neighbourhood in quadrant II had a high physical condition value and a low sustainability value. It, therefore, needs to prioritise a revitalisation strategy. The XL neighbourhood performed poorly with regard to balanced development and ranked behind most neighbourhoods on social aspects. Specifically, more than three-quarters of residents gave bad comments with regard to the current provision of public resources, especially for green areas, open space, and facilities for children and ageing groups. In addition, more than $80 \%$ of residents did not get involved in neighbourhood activities because of poor-information and a lack of attractiveness although there was a veritable wealth of activities available in the XL neighbourhood. In light of this, it is suggested that the XL neighbourhood should further promote neighbourhood interaction through the strength of residents' self-organisation and enhance accessibility to, and the variety of, quality facilities.

Rehabilitation can be regarded as the primary strategy that should be embraced by the LSX neighbourhood in quadrant IV. This is due to the low value that was recorded with regard to physical conditions. Timely repair and maintenance not only ensure safety within the living environment but also help to sustain property value. The LSX neighbourhood can focus on improving transportation conditions through a range of approaches; promoting pedestrian networks, increasing road network density, and enhancing access to quality public facilities, especially leisure and green facilities. As for building conditions, the LSX neighbourhood ranked in the middle. Carrying out appropriate maintenance upon buildings is, therefore, encouraged. The Urban Renewal Authority in Hong Kong has launched a series of actions to assistant property owners 
in promoting and facilitating proper repair and maintenance of buildings since 2004 . Measures have included financial subsidies, technical assistance, and preventive maintenance; all of these can serve as references for Yuzhong district to deal with the physical problems that it presently exhibits.

The values recorded for sustainability and physical conditions in the LH neighbourhood were comparatively high compared with other neighbourhoods in quadrant III. This indicates that the LH neighbourhood can select multiple strategies (i.e., the second path and the fourth path) according to the decision-making matrix. Despite these positives, the LH neighbourhood performed worst in terms of living environment in both objective and subjective evaluations although the value that it received with regard to physical building conditions was relatively high. Cumulatively, this suggests there is an urgent need to address function decay. Therefore, partial rebuilding (i.e., the fourth path) should be implemented first. To deal with its own problems, the LH neighbourhood needs to implement demand-led rebuilding. Suffering massive population flows and severe pollution issues, the LH neighbourhood can improve its internal vibrancy by providing more green public open space and facilities, enhancing its waste circulation network, and promoting better access to various facilities.

The HW neighbourhood in region B of quadrant III should firstly implement a partial rebuilding strategy to enhance sustainability and then carry out a rehabilitation strategy to improve physical conditions within its territories. Considering the fact that the HW neighbourhood has the largest population among the eight neighbourhoods, the practical approaches that need to be taken by the HW neighbourhood are not only about renewing the dilapidated area but also about improving the living standards enjoyed by displaced households. Most importantly, compensation, rehousing arrangements, and a realistic time schedule should be given attention. The GYS neighbourhood in region D can improve its physical conditions by implementing an internal refurbishment strategy. Revitalisation can, thereafter, be undertaken to promote the sustainability of the entire neighbourhood. With the bad building conditions that exist within the GYS neighbourhood, medium-scale refurbishment should be adopted. This should include partially reinforcing the main building structure, improving the building surface, and reorganising the internal layout of the flats.

Table 4 summarises the details of each strategy by content, characteristics and associated practical approaches. Other factors, such as compensation subsidies, financial feasibility, residents' resettlement, and stakeholder interests, also need to be considered in practice. 
Physical conditions

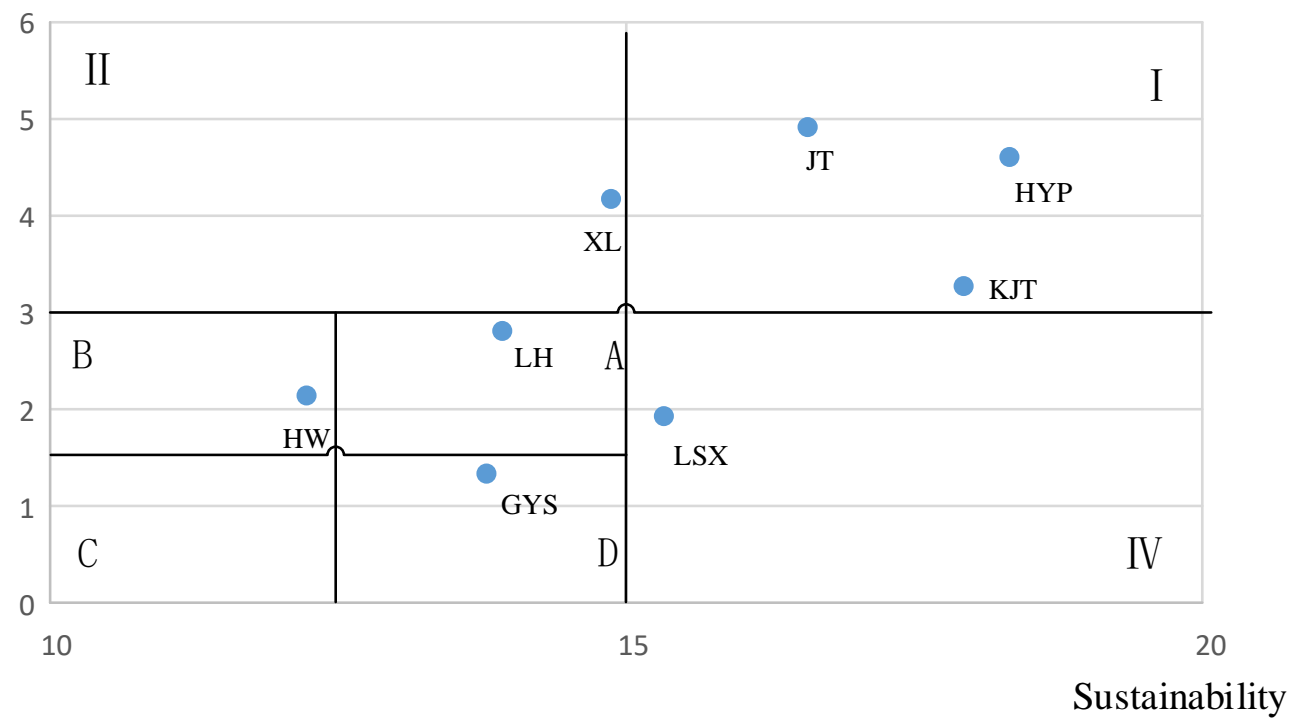

Figure 7. Analytical results from the decision-making matrix. 
Table 4. Different strategies and practical approaches.

\begin{tabular}{|c|c|c|c|c|c|}
\hline No & Category & Meaning & Characteristics & Practice approaches & Focus \\
\hline 1 & Redevelopment & $\begin{array}{l}\text { Improve the built environment } \\
\text { and infrastructure in entire old } \\
\text { areas through comprehensive } \\
\text { planning and development }\end{array}$ & $\begin{array}{l}\text { Improve both physical } \\
\text { conditions and sustainability } \\
\text { when the values of the two } \\
\text { aspects are low }\end{array}$ & $\begin{array}{l}\text { 1. Adjust the structure of urban land utilization (proportion of } \\
\text { every function) } \\
\text { 2. Adjust the space layout } \\
\text { 3. Reconstruct the structure of functions (function zoning) ... }\end{array}$ & $\begin{array}{l}\text { Physical and } \\
\text { functional decay }\end{array}$ \\
\hline 2 & $\begin{array}{l}\text { Internal } \\
\text { refurbishment }\end{array}$ & $\begin{array}{l}\text { Refurbish the interior of } \\
\text { existing buildings and facilities } \\
\text { to improve physical conditions }\end{array}$ & $\begin{array}{l}\text { Improve physical conditions } \\
\text { when the values are low }\end{array}$ & $\begin{array}{l}\text { 1. Large-scale refurbishment } \\
\text { 2. Medium-scale refurbishment } \\
\text { 3. Small-scale refurbishment ... }\end{array}$ & Physical decay \\
\hline 3 & Revitalisation & $\begin{array}{l}\text { Create a vital atmosphere and } \\
\text { enhance the entire } \\
\text { neighbourhood by considering } \\
\text { local characteristics }\end{array}$ & $\begin{array}{l}\text { Improve sustainability when } \\
\text { physical condition value is } \\
\text { high and sustainability value } \\
\text { is low }\end{array}$ & $\begin{array}{l}\text { 1. Change functions of buildings } \\
\text { 2. Increase the functional diversity } \\
\text { 3. Adjust the social-economic structure ... }\end{array}$ & Functional decay \\
\hline 4 & $\begin{array}{l}\text { Partial } \\
\text { rebuilding }\end{array}$ & $\begin{array}{l}\text { Rebuilt the buildings and } \\
\text { infrastructures in some old } \\
\text { areas }\end{array}$ & $\begin{array}{l}\text { Improve sustainability when } \\
\text { the values of physical } \\
\text { conditions and sustainability } \\
\text { are low }\end{array}$ & $\begin{array}{l}\text { 1. Renovate public spaces (public greening, gathering points) } \\
\text { 2. Allocate resources and functions optimally ... }\end{array}$ & Functional decay \\
\hline 5 & Rehabilitation & $\begin{array}{l}\text { Rehabilitate existing structures } \\
\text { in-situ to prolong the lifespan } \\
\text { of buildings and slow down the } \\
\text { pace of urban decay. }\end{array}$ & $\begin{array}{l}\text { Improve physical conditions } \\
\text { when physical condition } \\
\text { value is low and } \\
\text { sustainability value is high }\end{array}$ & $\begin{array}{l}\text { 1. Improve building conditions comprehensively } \\
\text { 2. Improve infrastructure conditions comprehensively } \\
\text { 3. Optimize the quality of existing buildings ... }\end{array}$ & Physical decay \\
\hline
\end{tabular}


Note: Large-scale refurbishment means comprehensively reinforcing the main structure, improving the building surface, and reorganizing the layout; Medium-scale refurbishment means partially reinforcing the main structure, improving the building surface, and reorganizing the flat layout; Small-scale refurbishment means fixing walls, doors, and windows, as well as other minor maintenance (e.g., lift check and equipment replacement). 
These findings shed light on customised strategies and practical approaches for urban renewal at the neighbourhood scale. In so doing, special attention is paid to address specific problems and response to local characteristics and how these may vary from one neighbourhood to another. To maximise neighbourhood-level urban renewal, an efficient decision-making process requires general strategies to be tailored to local contexts. This can, as this study has shown, be most readily achieved by implanting both 'top-down' policy instruments and 'bottom-up' field investigations. Drawing on the proposed decision-making framework, decision-makers are capable of locating key areas and adjusting practical approaches from the 'one size fits all' approach to ensure that small-scale improvements are customised to the specific demands of individual residents within individual neighbourhoods. This is a process that can be further informed - and bettered - via the use of in-depth investigations into the interconnections and functions of various neighbourhoods within a city.

As this study shows, the consideration of residents' behaviour and preferences demonstrates that people's perceptions can provide invaluable information about the local context and the direction that neighbourhood renewal ought to take if it is to maximise residents' utility. To bring benefits to the entire society and mitigate against social instability, public participation is required in the future to ensure that urban renewal policy-making always delivers a win-win situation.

\section{Conclusion}

As a consequence of the ongoing processes of rapid urbanisation in China, cities are faced with a scarcity of land resources and an array of associated urban problems; some are generic while others are locality-specific. Urban renewal initiatives provide great opportunities for the sustainable development of cities. In light of the problems that Chinese cities face, this paper proposes a decision-making framework for urban renewal at the neighbourhood level, where most development projects take place within cities. Different from previous studies, this framework is adaptive to Chinese contexts by providing different paths and strategies for various scenarios in urban renewal through an indicator system and a decision-making matrix. Via the case study of eight neighbourhoods in the Yuzhong District of Chongqing, China, the proposed framework has presented practical and effective evaluations of the current conditions that exist within the selected neighbourhoods. The findings indicate that sustainability is dynamic and complex. Contradictions exist between the results obtained from the top-down analysis from the perspective of policy-makers and bottom-up analysis informed by the perspective of residents. Such disparities suggest that there is a need for a comprehensive and dynamic evaluation of neighbourhoods from multiple dimensions. 
This more holistic approach coves both subjective and objective aspects and is of great importance for decision-making. The proposed framework can shed light on other cities that possess similar local characteristics. The proposed framework is also adaptable as it emphasises specific dimensions that echo to local characteristics.

As this study has noted, there are other factors that also play important roles in urban renewal initiatives. These include, but are not limited to, the financial feasibility of proposed programmes, issues surrounding residents' resettlement, and public participation. Such issues are not, however, the focus of this paper though future studies upon these aspects would be informed by the results presented herein. It is also suggested that there is a need to integrate multi-scale assessments in the future from the city level to the neighbourhood level, and from the neighbourhood level to the building level if we wish to fully address the interactions and influences that exist between different spatial scales. In addition, multiple stakeholders with various interests are involved in the urban renewal process. It is suggested to develop a framework that includes voices from different stakeholders and show the results in an appropriate way to accommodate end-users' preferences.

\section{Acknowledgements}

The authors wish to express their sincere gratitude to the Natural Science Foundation of China (Grant No. 71801023), Chongqing Science \& Technology Commission (No. cstc2018jcyjAX0099), and the Fundamental Research Funds for the Central Universities (No. 2017CDJSK03XK05) for funding this research project. The authors would like to give their sincere gratitude to Dr. Bertie Dockerill for his kind suggestions on manuscript proofreading. Appreciation is also due to all members of the research team for their invaluable contributions.

\section{References}

ADAMSA, D. \& HASTINGS, E. M. 2001. Urban renewal in Hong Kong: transition from development corporation to renewal authority. Land Use Policy, 18, 245-258.

ALMEIDA, C. P., RAMOS, A. F. \& SILVA, J. M. 2018. Sustainability assessment of building rehabilitation actions in old urban centres. Sustainable Cities and Society, 36, 378-385.

BOGGIA, A. \& CORTINA, C. 2010. Measuring sustainable development using a multi-criteria model: a case study. J Environ Manage, 91, 2301-6.

BROMley, R. D. F., TALlON, A. R. \& THOMAS, C. J. 2005. City Centre Regeneration through Residential Development: Contributing to Sustainability. Urban Studies, 42, 2407-2429.

CHAN, E. H. W. \& YUNG, E. H. K. 2004. Is the development control legal framework conducive to a sustainable dense urban development in Hong Kong? Habitat International, 28, 409-426.

CHOGUILL, C. L. 2008. Developing sustainable neighbourhoods. Habitat International, 32, 41-48. 
DOGRUYOL, K., AZIZ, Z. \& ARAYICI, Y. 2018. Eye of Sustainable Planning: A Conceptual HeritageLed Urban Regeneration Planning Framework. Sustainability, 10, 1343.

DONALDSON, R. \& DU PLESSIS, D. 2013. The urban renewal programme as an area-based approach to renew townships: The experience from Khayelitsha's Central Business District, Cape Town. Habitat International, 39, 295-301.

FARID, K. 2011. Urban Sprawl Vs Urban Renewal: What Role for Town and Country Planning Instruments in Ensuring Sustainable Cities? Case of Algeria. Procedia Engineering, 21, 760766.

GLASSON, J. \& WOOD, G. 2009. Urban regeneration and impact assessment for social sustainability. Impact Assessment and Project Appraisal, 27, 283-290.

GREIG, A., EL-HARAM, M. \& HORNER, M. 2010. Using deprivation indices in regeneration: Does the response match the diagnosis? Cities, 27, 476-482.

HEMPHILL, L., BERRY, J. \& MCGREAL, S. 2004. An Indicator-based Approach to Measuring Sustainable Urban Regeneration Performance: Part 1, Conceptual Foundations and Methodological Framework. Urban Studies, 41, 725-755.

HIREMATH, R. B., BALACHANDRA, P., KUMAR, B., BANSODE, S. S. \& MURALI, J. 2013. Indicator-based urban sustainability_A review. Energy for Sustainable Development, 17, 555 563.

HO, D. C. W., YAU, Y., POON, S. W. \& LIUSMAN, E. 2012. Achieving Sustainable Urban Renewal in Hong Kong:Strategy for Dilapidation Assessment of High Rises. Urban Planning and Development, 138, 153-165.

HUTCHINS, M. J. \& SUTHERLAND, J. W. 2008. An exploration of measures of social sustainability and their application to supply chain decisions. Journal of Cleaner Production, 16, 1688-1698.

KAMBLE, T. \& BAHADURE, S. 2019. Neighborhood sustainability assessment in developed and developing countries. Environment, Development and Sustainability.

KARATAS, A. \& EL-RAYES, K. 2015. Evaluating the performance of sustainable development in urban neihgbourhoods based on the feedback of multiple stakeholders. Sustainable Cities and Society, 14, 374-382.

KOMEILY, A. \& SRINIVASAN, R. S. 2016. What is Neihgbourhood Context and Why does it Matter in Sustainability Assessment? Procedia Engineering, 145, 876-883.

KWATRA, S., KUMAR, A., SHARMA, P., SHARMA, S. \& SINGHAL, S. 2016. Benchmarking sustainability using indicators: An Indian case study. Ecological Indicators, 61, 928-940.

LEE, Y.-J. \& HUANG, C.-M. 2007. Sustainability index for Taipei. Environmental Impact Assessment Review, 27, 505-521.

LI, F., LIU, X., HU, D., WANG, R., YANG, W., LI, D. \& ZHAO, D. 2009. Measurement indicators and an evaluation approach for assessing urban sustainable development: A case study for China's Jining City. Landscape and Urban Planning, 90, 134-142.

LIU, F., ZHANG, Z., SHI, L., ZHAO, X., XU, J., YI, L., LIU, B., WEN, Q., HU, S., WANG, X., ZUO, L., LI, N. \& LI, M. 2016. Urban expansion in China and its spatial-temporal differences over 
the past four decades. Journal of Geographical Sciences, 26, 1477-1496.

LIU, F., ZHANG, Z., ZHAO, X., WANG, X., ZUO, L., WEN, Q., YI, L., XU, J., HU, S. \& LIU, B. 2019. Chinese cropland losses due to urban expansion in the past four decades. Science of The Total Environment, 650, 847-857.

LUCAS, K., FULLER, S., PSAILA, A. \& THRUSH, D. 2004. Prioritising local environment concerns, York Publishing Services Ltd.

LUKE, B., KATHY, M. \& FRANçOIS, V. 2018. A Critique of the Application of Neighborhood Sustainability Assessment Tools in Urban Regeneration. Sustainability, 10, 1005.

MANUPATI, V. K., RAMKUMAR, M. \& SAMANTA, D. 2018. A multi-criteria decision making approach for the urban renewal in Southern India. Sustainable Cities and Society, 42, 471-481.

MATEO, C. \& CUñAT, A. 2016. Guide of strategies for urban regeneration: A design-support tool for the Spanish context. Ecological Indicators, 64, 194-202.

MAZZA, L. \& RYDIN, Y. 1997. Urban Sustainability: Discourses, Networks and Policy Tools. Progress in Planning, 47, 1-47.

MCDONALD, S., MALYS, N. \& MALIENĖ, V. 2009. Urban regeneration for sustainable communities: A case study. Technological and Economic Development of Economy, 15, 49-59.

MCGREGOR, A. \& MCCONNACHIE, M. 1995. Social Exclusion, Urban Regeneration and Economic Reintegration. Urban Studies, 32, 1587-1600.

MEHDIPANAH, R., MALMUSI, D., MUNTANER, C. \& BORRELL, C. 2013. An evaluation of an urban renewal program and its effects on neihgbourhood resident's overall wellbeing using concept mapping. Health \& Place, 23, 9-17.

MOHAN, G., LONGO, A. \& KEE, F. 2018. The effect of area based urban regeneration policies on fuel poverty: Evidence from a natural experiment in Northern Ireland. Energy Policy, 114, 609-618.

MORENO PIRES, S., FIDéLIS, T. \& RAMOS, T. B. 2014. Measuring and comparing local sustainable development through common indicators: Constraints and achievements in practice. Cities, 39, $1-9$.

MOUSSIOPOUlOS, N., ACHILlAS, C., VlACHOKOSTAS, C., SPYRIDI, D. \& NIKOLAOU, K. 2010. Environmental, social and economic information management for the evaluation of sustainability in urban areas: A system of indicators for Thessaloniki, Greece. Cities, 27, 377384.

MUNIER, N. 2011. Methodology to select a set of urban sustainability indicators to measure the state of the city, and performance assessment. Ecological Indicators, 11, 1020-1026.

MUSTERD, S. \& OSTENDORF, W. 2008. Integrated urban renewal in The Netherlands: a critical appraisal. Urban Research \& Practice, 1, 78-92.

NAVRATIL, J., PICHA, K., MARTINAT, S., NATHANAIL, P. C., TURECKOVA, K. \& HOLESINSKA, A. 2018. Resident's preferences for urban brownfield revitalization: Insights from two Czech cities. Land Use Policy, 76, 224-234.

O'RIORDAN, T. 2004. Environmental science, sustainability and politics. Trans Inst Br Geogr, 234-247.

PENG, Y., LAI, Y., LI, X. \& ZHANG, X. 2015. An alternative model for measuring the sustainability of 
urban regeneration: the way forward. Journal of Cleaner Production, 109, 76-83.

RANDOLPH, B. \& FREESTONE, R. 2012. Housing Differentiation and Renewal in Middle-ring Suburbs: The Experience of Sydney, Australia. Urban Studies, 49, 2557-2575.

RIERA PéREZ, M. G., LAPRISE, M. \& REY, E. 2018. Fostering sustainable urban renewal at the neighborhood scale with a spatial decision support system. Sustainable Cities and Society, 38, 440-451

ROBERTS, P. \& SYKES, H. 1999. Urban Regeneration: A handbook.

ROHE, W. M. 2009. From Local to Global: One Hundred Years of Neihgbourhood Planning. Journal of the American Planning Association, 75, 209-230.

SALINAS VARELA, E. \& BAERISWYL RADA, S. 2017. The Ribera Norte Urban Recovery Program; Twenty years of successes and failures of a policy of urban projects in Chile. Revista De Urbanismo, 36, 114-130.

SHARIFI, A. \& MURAYAMA, A. 2013. A critical review of seven selected neihgbourhood sustainability assessment tools. Environmental Impact Assessment Review, 38, 73-87.

SHARIFI, A. \& MURAYAMA, A. 2014. Neihgbourhood sustainability assessment in action: Crossevaluation of three assessment systems and their cases from the US, the UK, and Japan. Building and Environment, 72, 243-258.

SHI, Q., YU, T., ZUO, J. \& LAI, X. 2016. Challenges of developing sustainable neighborhoods in China. Journal of Cleaner Production, 135, 972-983.

TANGUAY, G. A., RAJAONSON, J., LEFEBVRE, J.-F. \& LANOIE, P. 2010. Measuring the sustainability of cities: An analysis of the use of local indicators. Ecological Indicators, 10, $407-$ 418.

TIN, W. J. \& LEE, S. H. 2017. Development of neighbourhood renewal in Malaysia through case study for middle income households in New Village Jinjang, Kuala Lumpur. Sustainable Cities and Society, 32, 191-201.

WANG, A., HU, Y., LI, L. \& LIU, B. 2016. Group Decision Making Model of Urban Renewal Based on Sustainable Development: Public Participation Perspective. Procedia Engineering, 145, 15091517.

WANG, H., SHEN, Q., TANG, B.-S., LU, C., PENG, Y. \& TANG, L. 2014. A framework of decisionmaking factors and supporting information for facilitating sustainable site planning in urban renewal projects. Cities, 40, 44-55.

WANG, Y. \& XIANG, P. 2019. Investigate the Conduction Path of Stakeholder Conflict of Urban Regeneration Sustainability in China: the Application of Social-Based Solutions. Sustainability, 11.

WILLIAMS, K. \& DAIR, C. 2007. A framework for assessing the sustainability of brownfield developments. Journal of Environmental Planning and Management, 50, 23-40.

YANG, J. 2017. Integrated Sustainability Assessment and Renewal of Old Industrial Areas: A Case Study on Changzhou. Procedia Engineering, 180, 136-145.

YAU, Y. S. \& CHAN, H. L. 2008. To rehabilitate or redevelop: A study of the decision criteria for urban 
regeneration projects. Journal of Place Management and Development, 1, 272-291.

YI, Z., LIU, G., LANG, W., SHRESTHA, A. \& MARTEK, I. 2017. Strategic Approaches to Sustainable Urban Renewal in Developing Countries: A Case Study of Shenzhen, China. Sustainability, 9.

YU, A. T. W., WU, Y., ZHENG, B., ZHANG, X. \& SHEN, L. 2014. Identifying risk factors of urbanrural conflict in urbanisation: A case of China. Habitat International, 44, 177-185.

ZELlNER, M. L., THEIS, T. L., KARUNANITHI, A. T., GARMESTANI, A. S. \& CABEZAS, H. 2008. A new framework for urban sustainability assessments: Linking complexity, information and policy. Computers, Environment and Urban Systems, 32, 474-488.

ZHANG, C., MIAO, C., ZHANG, W. \& CHEN, X. 2018. Spatiotemporal patterns of urban sprawl and its relationship with economic development in China during 1990-2010. Habitat International, $79,51-60$.

ZHENG, H. W., SHEN, G. Q. \& WANG, H. 2014. A review of recent studies on sustainable urban renewal. Habitat International, 41, 272-279.

ZHENG, H. W., SHEN, G. Q. P., SONG, Y., SUN, B. \& HONG, J. 2017. Neihgbourhood sustainability in urban renewal: An assessment framework. Environment and Planning B: Urban Analytics and City Science, 44, 903-924.

ZHENG, W., SHEN, G. Q., WANG, H., HONG, J. \& LI, Z. 2017. Decision support for sustainable urban renewal: A multi-scale model. Land Use Policy, 69, 361-371. 
Appendix A. Indicators of sustainability and physical conditions for neighbourhood in urban renewal.

\begin{tabular}{|c|c|c|c|c|c|c|}
\hline Dimension & Category & Sub-category & Indicator & Data source & Measurement & Reference \\
\hline \multirow[t]{17}{*}{ Sustainability } & \multirow[t]{17}{*}{ Social } & \multirow[t]{3}{*}{ Population } & Population density & Statistical yearbook & $\begin{array}{l}\text { Population/are of the planning } \\
\text { unit }\end{array}$ & $\begin{array}{l}\text { Boggia and Cortina (2010); Lee and } \\
\text { Huang (2007); Zheng et al. (2016) }\end{array}$ \\
\hline & & & Diversity of ages & Statistical yearbook & $\frac{1}{\text { number of types }} \sum_{i}\left(1-\frac{\text { population in type } \mathrm{i}}{\text { objective population in type } \mathrm{i}}\right)^{2}$ & Zheng et al. (2016) \\
\hline & & & Population growth rate & Statistical yearbook & Natural growth rate & Hutchins and Sutherland (2008) \\
\hline & & Housing & $\begin{array}{l}\text { Residential floor area } \\
\text { per capita }\end{array}$ & Statistical yearbook & Residential floor area/population & Zheng et al. (2016) \\
\hline & & Education & Mean of education & Questionnaire & Mean of education & Li et al. (2009) \\
\hline & & Health & $\begin{array}{l}\text { Average population } \\
\text { served per Bed in the } \\
\text { government hospital }\end{array}$ & Statistical yearbook & $\begin{array}{l}\text { Beds in government } \\
\text { hospital/population }\end{array}$ & $\begin{array}{l}\text { Kwatra et al. (2016); Li et al. } \\
\text { (2009) }\end{array}$ \\
\hline & & Security & Crime Rates & None & Crime population/population & $\begin{array}{l}\text { Komeily and Srinivasan (2016); } \\
\text { Tanguay et al. (2010) }\end{array}$ \\
\hline & & \multirow[t]{2}{*}{ Equity } & $\begin{array}{l}\text { The ratio of average } \\
\text { female wage to male } \\
\text { wage }\end{array}$ & Statistical yearbook & $\begin{array}{l}\text { Average female wage /average } \\
\text { male wage }\end{array}$ & Hutchins and Sutherland (2008) \\
\hline & & & $\begin{array}{l}\text { Female/male } \\
\text { employment rate }\end{array}$ & Statistical yearbook & $\begin{array}{l}\text { Female employment rate/male } \\
\text { employment rate }\end{array}$ & Lee and Huang (2007) \\
\hline & & \multirow[t]{3}{*}{ Transportation } & $\begin{array}{l}\text { Per capita pedestrian } \\
\text { walkway index }\end{array}$ & $\begin{array}{l}\text { Spatial analysis in } \\
\text { GIS }\end{array}$ & $\begin{array}{l}\text { Length /area of pedestrian } \\
\text { walkway/ population }\end{array}$ & Lee and Huang (2007) \\
\hline & & & $\begin{array}{l}\text { Diversity of public } \\
\text { transport }\end{array}$ & Field survey & $\frac{1}{\text { number of types }} \sum_{1}\left(1-\frac{\text { population in type } \mathrm{i}}{\text { objective population in type i }}\right)^{2}$ & Zheng et al. (2016) \\
\hline & & & $\begin{array}{l}\text { Per capita parking } \\
\text { spaces provision }\end{array}$ & Field survey & Parking spaces /population & Hemphill et al. (2004) \\
\hline & & \multirow[t]{2}{*}{ Facilities } & $\begin{array}{l}\text { Participation in public } \\
\text { facilities }\end{array}$ & Questionnaire & $\begin{array}{l}\text { Number of participants as } \\
\text { percentage of total population }\end{array}$ & Tanguay et al. (2010) \\
\hline & & & Diversity of facilities & $\begin{array}{l}\text { Spatial analysis in } \\
\text { GIS }\end{array}$ & $\frac{1}{\text { number of types }} \sum_{i}\left(1-\frac{\text { number of faci i ity } \mathrm{i}}{\text { objective number of faci ity i }}\right)^{2}$ & Zheng et al. (2016) \\
\hline & & \multirow[t]{2}{*}{ Well-being } & Cost of living & Questionnaire & Cost of living in per person & Tanguay et al. (2010) \\
\hline & & & $\begin{array}{l}\text { Satisfaction on cultural } \\
\text { activities }\end{array}$ & Questionnaire & $\begin{array}{l}\text { Average value of satisfaction on } \\
\text { cultural activities }\end{array}$ & Lee and Huang (2007) \\
\hline & & Income & $\begin{array}{l}\text { Average personal } \\
\text { income }\end{array}$ & Statistical yearbook & Disposable incomes/population & Lee and Huang (2007) \\
\hline
\end{tabular}


Appendix A. Continued.

\begin{tabular}{|c|c|c|c|c|c|c|}
\hline Dimension & Category & Sub-category & Indicator & Data source & Measurement & Reference \\
\hline \multirow[t]{12}{*}{ Sustainability } & \multirow[t]{4}{*}{ Social } & Employment & Unemployment rate & $\begin{array}{l}\text { Spatial analysis in } \\
\text { GIS }\end{array}$ & $\begin{array}{l}\text { Unemployed } \\
\text { persons/population }\end{array}$ & $\begin{array}{l}\text { Tanguay et al. (2010); Boggia and } \\
\text { Cortina (2010); Lee and Huang (2007) }\end{array}$ \\
\hline & & \multirow[t]{2}{*}{ Companies } & $\begin{array}{l}\text { Diversity of business } \\
\text { activities }\end{array}$ & Field survey & $\frac{1}{\text { number of groups }} \sum \sum_{1}\left(1-\frac{\text { nubber of buiness category i }}{\text { objective number of buiness category i }}\right)^{2}$ & Zheng et al. (2016) \\
\hline & & & $\begin{array}{l}\text { Density of small business } \\
\text { with local characteristic }\end{array}$ & Field survey & $\begin{array}{l}\text { Number of small businesses } \\
\text { /area of the neighbourhood }\end{array}$ & Zheng et al. (2016) \\
\hline & & GDP & GDP density & $\begin{array}{l}\text { Statistical } \\
\text { yearbook }\end{array}$ & GDP/(area*population) & Li et al. (2009) \\
\hline & \multirow[t]{8}{*}{$\begin{array}{l}\text { Environ } \\
\text { ment }\end{array}$} & \multirow[t]{3}{*}{ Resources } & Water resources & $\begin{array}{l}\text { Water resources } \\
\text { bulletin }\end{array}$ & $\begin{array}{l}\text { Total water } \\
\text { resources/population }\end{array}$ & Moussiopoulos et al. (2010) \\
\hline & & & $\begin{array}{l}\text { Water Quality for Human } \\
\text { Consumption }\end{array}$ & $\begin{array}{l}\text { Water resources } \\
\text { bulletin }\end{array}$ & $\begin{array}{l}\text { Proportion of the urban } \\
\text { drinking water supply that is } \\
\text { safe to drink according to the } \\
\text { national standards }\end{array}$ & $\begin{array}{l}\text { Moreno Pires et al. (2014); Karatas } \\
\text { and El-Rayes (2015); Lee and Huang } \\
\text { (2007); Li et al. (2009) }\end{array}$ \\
\hline & & & Vegetation rate & $\begin{array}{l}\text { Spatial analysis in } \\
\text { GIS }\end{array}$ & $\begin{array}{l}\text { The area of land covered with } \\
\text { vegetation /area of community }\end{array}$ & $\begin{array}{l}\text { Wang et al. (2014); Li et al. (2009); } \\
\text { Zellner et al. (2008) }\end{array}$ \\
\hline & & \multirow[t]{2}{*}{ Resources use } & $\begin{array}{l}\text { Daily water consumption } \\
\text { per person }\end{array}$ & $\begin{array}{l}\text { Water resources } \\
\text { bulletin }\end{array}$ & $\begin{array}{l}\text { Daily water } \\
\text { consumption/population }\end{array}$ & $\begin{array}{l}\text { Tanguay et al. (2010); Lee and Huang } \\
\text { (2007); Li et al. (2009); Boggia and } \\
\text { Cortina (2010); Zheng et al. (2016) }\end{array}$ \\
\hline & & & $\begin{array}{l}\text { Electricity } \\
\text { consumption per person }\end{array}$ & None & $\begin{array}{l}\text { Total electricity } \\
\text { consumption/population }\end{array}$ & $\begin{array}{l}\text { Lee and Huang (2007); Boggia and } \\
\text { Cortina (2010); Zheng et al. (2016) }\end{array}$ \\
\hline & & \multirow[t]{2}{*}{ Waste } & $\begin{array}{l}\text { Satisfaction on waste } \\
\text { management }\end{array}$ & Questionnaire & $\begin{array}{l}\text { Average value of satisfaction } \\
\text { on waste management }\end{array}$ & $\begin{array}{l}\text { Tanguay et al. (2010); Hemphill et } \\
\text { al. (2004) }\end{array}$ \\
\hline & & & $\begin{array}{l}\text { Per capita waste } \\
\text { generated }\end{array}$ & $\begin{array}{l}\text { Statistical } \\
\text { yearbook }\end{array}$ & $\begin{array}{l}\text { Total Waste generated/ } \\
\text { population }\end{array}$ & $\begin{array}{l}\text { Lee and Huang (2007); } \\
\text { Moussiopoulos et al. (2010); } \\
\text { Tanguay et al. (2010) }\end{array}$ \\
\hline & & Pollution & $\begin{array}{l}\text { Noise pollution: } \\
\text { satisfaction on noise }\end{array}$ & $\begin{array}{l}\text { Environmental } \\
\text { status bulletin }\end{array}$ & $\begin{array}{l}\text { Proportion of total days per } \\
\text { year in which noise levels } \\
\text { are above the level specified in } \\
\text { the national standard }\end{array}$ & $\begin{array}{l}\text { Wang et al. (2014); Boggia and } \\
\text { Cortina (2010); Moussiopoulos et al. } \\
\text { (2010); Li et al. (2009); Tanguay et al. } \\
\text { (2010) }\end{array}$ \\
\hline
\end{tabular}


Appendix A. Continued.

\begin{tabular}{|c|c|c|c|c|c|c|}
\hline Dimension & Category & Sub-category & Indicator & Data source & Measurement & Reference \\
\hline \multirow[t]{11}{*}{ Sustainability } & \multirow[t]{6}{*}{$\begin{array}{l}\text { Environ } \\
\text { ment }\end{array}$} & \multirow[t]{3}{*}{ Pollution } & GHG emissions & $\begin{array}{l}\text { Environmental } \\
\text { status bulletin }\end{array}$ & $\begin{array}{l}\text { Proportion of total days per } \\
\text { year in which GHG emission } \\
\text { levels are above the level } \\
\text { specified in the national } \\
\text { standard }\end{array}$ & $\begin{array}{l}\text { Tanguay et al. (2010); Boggia and } \\
\text { Cortina (2010); Moussiopoulos et al. } \\
\text { (2010); Li et al. (2009) }\end{array}$ \\
\hline & & & Satisfaction on air quality & $\begin{array}{l}\text { Environmental } \\
\text { status bulletin }\end{array}$ & $\begin{array}{l}\text { Proportion of total days per } \\
\text { year in which air quality levels } \\
\text { are above the level specified in } \\
\text { the national standard }\end{array}$ & $\begin{array}{l}\text { Li et al. (2009); Moreno Pires et al. } \\
\text { (2014); Zheng et al. (2016) }\end{array}$ \\
\hline & & & $\begin{array}{l}\text { Proportion of water areas } \\
\text { in which pollution levels } \\
\text { are below the limit } \\
\text { specified in the national } \\
\text { standards }\end{array}$ & $\begin{array}{l}\text { Environmental } \\
\text { status bulletin }\end{array}$ & $\begin{array}{l}\text { water areas in which pollution } \\
\text { levels are below the limit } \\
\text { specified in the national } \\
\text { standards/total water area }\end{array}$ & Li et al. (2009) \\
\hline & & \multirow[t]{3}{*}{ Others } & $\begin{array}{l}\text { Diversity of green } \\
\text { infrastructure }\end{array}$ & Field survey & $\frac{1}{\text { number of types }} \sum_{i}\left(1-\frac{\text { number of green infrastruct ture } i}{\text { objective number of grean infrastructure i i }}\right)^{2}$ & Li et al. (2009); Wang et al. (2016) \\
\hline & & & $\begin{array}{l}\text { Proportion of the } \\
\text { population that is satisfied } \\
\text { with their environment }\end{array}$ & Questionnaire & $\begin{array}{l}\text { Average value of satisfaction } \\
\text { on environment }\end{array}$ & Li et al. (2009) \\
\hline & & & $\begin{array}{l}\text { Sensory satisfaction on } \\
\text { esthetics }\end{array}$ & Questionnaire & $\begin{array}{l}\text { Average value of satisfaction } \\
\text { on esthetics }\end{array}$ & Wang et al. (2014) \\
\hline & \multirow[t]{5}{*}{ Land use } & \multirow[t]{5}{*}{ Land use form } & Land use for mix & $\begin{array}{l}\text { Spatial analysis } \\
\text { in GIS }\end{array}$ & $\begin{array}{l}-\sum_{i=1}^{n}[(\text { area of land use type i }) \\
* \ln (\text { area of land use type i })\end{array}$ & Zheng et al. (2016) \\
\hline & & & $\begin{array}{l}\text { Access to Public green } \\
\text { Spaces }\end{array}$ & $\begin{array}{l}\text { Spatial analysis } \\
\text { in GIS }\end{array}$ & $\begin{array}{l}\text { Area of publie greernspaces } \\
\text { within } 500 \mathrm{~m}\end{array}$ & $\begin{array}{l}\text { Sharifi and Murayama (2014); Wang } \\
\text { et al. (2016) }\end{array}$ \\
\hline & & & $\begin{array}{l}\text { Accessibility to } \\
\text { commercial services }\end{array}$ & $\begin{array}{l}\text { Spatial analysis } \\
\text { in GIS }\end{array}$ & $\begin{array}{l}\text { Number of commercial services } \\
\text { within } 500 \mathrm{~m}\end{array}$ & \\
\hline & & & $\begin{array}{l}\text { Accessibility to cultural } \\
\text { facilities }\end{array}$ & $\begin{array}{l}\text { Spatial analysis } \\
\text { in GIS }\end{array}$ & $\begin{array}{l}\text { Number of cultural facilities } \\
\text { within } 500 \mathrm{~m}\end{array}$ & Zheng et al. (2016) \\
\hline & & & $\begin{array}{l}\text { Accessibility to education } \\
\text { services }\end{array}$ & $\begin{array}{l}\text { Spatial analysis } \\
\text { in GIS }\end{array}$ & $\begin{array}{l}\text { Number of education services } \\
\text { within } 500 \mathrm{~m}\end{array}$ & Zheng et al. (2016) \\
\hline
\end{tabular}


Appendix A. Continued.

\begin{tabular}{|c|c|c|c|c|c|c|}
\hline Dimension & Category & Sub-category & Indicator & Data source & Measurement & Reference \\
\hline \multirow[t]{4}{*}{ Sustainability } & Land use & Land use form & $\begin{array}{l}\text { Accessibility to health care } \\
\text { services }\end{array}$ & Spatial analysis in GIS & $\begin{array}{l}\text { Number of health care services } \\
\text { within } 500 \mathrm{~m}\end{array}$ & Zheng et al. (2016) \\
\hline & & & $\begin{array}{l}\text { Accessibility to sport and } \\
\text { leisure facilities }\end{array}$ & Spatial analysis in GIS & $\begin{array}{l}\text { Number of sport and leisure } \\
\text { facilities within } 500 \mathrm{~m}\end{array}$ & Zheng et al. (2016) \\
\hline & & & Accessibility to other facilities & Spatial analysis in GIS & $\begin{array}{l}\text { Number of other facilities } \\
\text { within } 500 \mathrm{~m}\end{array}$ & Zheng et al. (2016) \\
\hline & & & Access to public transport & Spatial analysis in GIS & $\begin{array}{l}\text { Number of public transport } \\
\text { points within } 500 \mathrm{~m}\end{array}$ & Zheng et al. (2016) \\
\hline \multirow[t]{11}{*}{$\begin{array}{l}\text { Physical } \\
\text { conditions }\end{array}$} & $\begin{array}{l}\text { Building } \\
\text { conditions }\end{array}$ & & LEED certified buildings & Green building map & $\begin{array}{l}\text { Number of LEED-certified } \\
\text { buildings }\end{array}$ & $\begin{array}{l}\text { Karatas and El-Rayes } \\
(2015)\end{array}$ \\
\hline & & & Average building age & None & Average building age & Zheng et al. (2016) \\
\hline & & & $\begin{array}{l}\text { Number of buildings aged } \\
\text { above } 50 \text { years }\end{array}$ & None & Buildings aged above 50 years & Zheng et al. (2016) \\
\hline & & & Building maintenance & Questionnaire & $\begin{array}{l}\text { Average value of satisfaction on } \\
\text { building maintenance }\end{array}$ & Zheng et al. (2016) \\
\hline & & & Building density & Spatial analysis in GIS & Floor area/area of community & $\begin{array}{l}\text { Zheng et al. (2016); } \\
\text { Zellner et al. (2008) }\end{array}$ \\
\hline & Facilities & & Average Facilities age & Field survey & Average Facilities age & \\
\hline & conditions & & $\begin{array}{l}\text { Satisfaction on parks } \\
\text { conditions }\end{array}$ & Questionnaire & $\begin{array}{l}\text { Average value of satisfaction on } \\
\text { parks conditions }\end{array}$ & \\
\hline & & & $\begin{array}{l}\text { Public facility area ratio to } \\
\text { neighbourhood land areas }\end{array}$ & Spatial analysis in GIS & $\begin{array}{l}\text { Public facility area/area of } \\
\text { community }\end{array}$ & $\begin{array}{l}\text { Lee and Huang } \\
\text { (2007) }\end{array}$ \\
\hline & & & Density of road network & Spatial analysis in GIS & $\begin{array}{l}\text { Length of road/area of } \\
\text { community }\end{array}$ & $\begin{array}{l}\text { Moussiopoulos et al. } \\
(2010)\end{array}$ \\
\hline & & & $\begin{array}{l}\text { Proportion of the population } \\
\text { that is satisfied with their } \\
\text { transportation conditions }\end{array}$ & Questionnaire & $\begin{array}{l}\text { Average value of satisfaction on } \\
\text { transportation conditions }\end{array}$ & \\
\hline & & & $\begin{array}{l}\text { Proportion of the population } \\
\text { that is satisfied with their } \\
\text { leisure facilities }\end{array}$ & Questionnaire & $\begin{array}{l}\text { Average value of satisfaction on } \\
\text { leisure facilities }\end{array}$ & Tanguay et al. (2010) \\
\hline
\end{tabular}

Note: Data preparation for each source is shown in section four. As data sources may differ in different contexts, it is noteworthy that the data sources for each indicator here 
only apply to the case study in this research 
Appendix B. Questionnaire

Questionnaire about the sustainability in Yuzhong Distract, Chongqing

Part I Basic information survey

1. Where do you live?

$\square$ GYS $\quad \square$ JTJ $\quad \square$ XLJ $\quad \square$ LSX $\quad \square$ HYP $\quad \square$ KJT $\quad \square$ HWL $\quad \square$ LHL

2. What is your gender?

$\square$ Male $\quad \square$ Female

3. What is your age?

$\square 20$ or less $\quad \square 20-30 \quad \square 30-40 \quad \square 40-50 \quad \square 50-60 \quad \square 60$ or above

4. What is your profession?

$\square$ Farmer $\quad \square$ Factory worker $\quad \square$ Small business $\quad \square$ Civil servant

$\square$ Other public institution employee $\quad \square$ State-own enterprise employee

$\square$ Other enterprise employee $\quad \square$ Retired $\quad \square$ Unemployed $\quad \square$ Other

5. What is your highest educational diploma?

$\square$ Primary school and below $\quad \square$ Junior middle school $\quad \square$ High school/college

$\square$ Bachelor degree $\quad \square$ Master degree or above $\quad \square$ Other

6. How much is your monthly of living?
$\square 1000$ yuan or less
$\square 1000-2000$ yuan
$\square$ 2000-3000 yuan
$\square 3000-4000$ yuan
$\square 4000$ yuan or more yuan

7. What is your monthly income?
$\square 1000$ yuan or less
$\square 1000-2000$ yuan
$\square$ 2000-3000 yuan
$\square 3000-4000$ yuan
$\square 4000$ yuan or more
yuan

8 . The area of your home is

m2? ( $\square$ Floor area $\square$ Unit construction area)

9. What is the number of the resident population in your household?

\section{Part II Satisfaction survey}

10. Have you ever used the public facilities in your neighbourhood, including sports, cultural and entertainment facilities?

$\square$ Yes $\quad \square$ No

11. Have you participated in cultural activities held by your neighbourhood?

$\square$ Yes $\square$ No

12. Are you satisfied with the waste management in your neighbourhood such as recycling, garbage recycling, garbage disposal, etc.?

$\square$ Very good $\square$ Good $\quad \square$ General $\quad \square$ Bad $\quad \square$ Very bad

13. What is your overall satisfaction level with the natural and human environment in your neighbourhood?

$\square$ Very good $\quad \square$ Good $\quad \square$ General $\quad \square$ Bad $\quad \square$ Very bad

14. What is your satisfaction level with the ornamentalism of your neighbourhood?

$\square$ Very good $\square$ Good $\square$ General $\quad \square$ Bad $\quad \square$ Very bad

15. What is your satisfaction level with the air quality in your neighbourhood?

$\square$ Very good $\square$ Good $\square$ General $\quad \square$ Bad $\quad \square$ Very bad

16. What is your satisfaction level with the timeliness, efficiency, and practicality of government- 
organised building renovation activities in your neighbourhood?

$\square$ Very good $\quad \square$ Good $\quad \square$ General $\quad \square$ Bad $\quad \square$ Very bad

17. What is your satisfaction level with the park conditions in your neighbourhood, such as ornamentalism, functional diversity, functional practicability, etc.?

$\square$ Very good $\square$ Good $\square$ General $\quad \square$ Bad $\quad \square$ Very bad

18. What is your satisfaction level with the surrounding traffic conditions, such as travel convenience, traffic congestion, etc.?

$\square$ Very good $\quad \square$ Good $\quad \square$ General $\quad \square$ Bad $\quad \square$ Very bad

19. What is your satisfaction level with the greening of your neighbourhood, such as ornamentalism, diversity, suitability, etc.?

$\square$ Very good $\quad \square$ Good $\quad \square$ General $\quad \square$ Bad $\quad \square$ Very bad

20. What is your satisfaction level with the leisure and entertainment facilities in your neighbourhood, such as diversity and practicality?

$\square$ Very good $\square$ Good $\quad \square$ General $\quad \square$ Bad $\quad \square$ Very bad

21. What is your satisfaction level with your neighbourhood's protection of historic buildings?

$\square$ Very good $\quad \square$ Good $\quad \square$ General $\quad \square$ Bad $\quad \square$ Very bad

22. Have you participated in public affairs, such as voting, suggestions, etc.?

$\square$ Yes $\quad \square$ No 